\title{
The Genomics and Molecular Biology of Natural Killer/T-Cell Lymphoma: Opportunities for Translation
}

\author{
Sanjay de Mel ${ }^{1}$, Gwyneth Shook-Ting Soon ${ }^{2}$, Yingting Mok ${ }^{2}$, Tae-Hoon Chung ${ }^{3}$, \\ Anand D. Jeyasekharan 1,3, Wee-Joo Chng 1,3,*(1) and Siok-Bian Ng 2,3,4,* \\ 1 Department of Haematology-Oncology, National University Cancer Institute of Singapore, National \\ University Health System, Singapore 110974, Singapore; sanjay_widanalage@nuhs.edu.sg (S.d.M.); \\ anand_jeyasekharan@nuhs.edu.sg (A.D.J.) \\ 2 Department of Pathology, National University Hospital, National University Health System, \\ Singapore 110974, Singapore; gwyneth.soon@mohh.com.sg (G.S.-T.S.); yingting.mok@mohh.com.sg (Y.M.) \\ 3 Cancer Science Institute of Singapore, National University of Singapore, Singapore 110974, Singapore; \\ hoontaechung@gmail.com \\ 4 Department of Pathology, Yong Loo Lin School of Medicine, National University of Singapore, \\ Singapore 119074, Singapore \\ * $\quad$ Correspondence: mdccwj@nus.edu.sg (W.-J.C.); patnsb@nus.edu.sg (S.-B.N.); Tel.: +65-6772-4709 (S.-B.N.)
}

Received: 29 May 2018; Accepted: 25 June 2018; Published: 30 June 2018

Abstract: Extranodal NK/T-cell lymphoma, nasal type (ENKTL), is an aggressive malignancy with a poor prognosis. While the introduction of L-asparaginase in the treatment of this disease has significantly improved the prognosis, the outcome of patients relapsing after asparaginase-based chemotherapy, which occurs in up to $50 \%$ of patients with disseminated disease, remains dismal. There is hence an urgent need for effective targeted therapy especially in the relapsed/refractory setting. Gene expression profiling studies have provided new perspectives on the molecular biology, ontogeny and classification of ENKTL and further identified dysregulated signaling pathways such as Janus associated kinase (/Signal Transducer and activation of transcription (JAK/STAT), Platelet derived growth factor (PDGF), Aurora Kinase and NF- $k$ B, which are under evaluation as therapeutic targets. Copy number analyses have highlighted potential tumor suppressor genes such as PR Domain Zinc Finger Protein 1 (PRDM1) and protein tyrosine phosphatase kappa (PTPRK) while next generation sequencing studies have identified recurrently mutated genes in pro-survival and anti-apoptotic pathways. The discovery of epigenetic dysregulation and aberrant microRNA activity has broadened our understanding of the biology of ENKTL. Importantly, immunotherapy via Programmed Cell Death -1 (PD-1) and Programmed Cell Death Ligand1 (PD-L1) checkpoint signaling inhibition is emerging as an attractive therapeutic strategy in ENKTL. Herein, we present an overview of the molecular biology and genomic landscape of ENKTL with a focus on the most promising translational opportunities.

Keywords: NK/T-cell lymphoma; genomics; Gene expression profiling (GEP); copy number; epigenetics; immune checkpoint; targeted therapy

\section{Introduction}

EBV-associated T-cell or NK-cell lymphoproliferative diseases encompass several disease entities with differing clinical and pathologic findings. The two prototypical entities are extranodal NK/T-cell lymphoma, nasal type (ENKTL) and aggressive NK-cell leukemia (ANKL) [1]. ENKTL is a highly aggressive lymphoma derived from mature NK cells or cytotoxic T cells with a strong association with Epstein Barr Virus (EBV). The disease almost always has an extranodal presentation and classically 
involves the nasal cavity or upper aerodigestive tract. Other sites of extranasal involvement include skin, soft tissue and gastrointestinal tract. Overall, about $85 \%$ of nasal ENKTL are derived from NK cells but only about $50 \%$ of those occurring in the extranasal sites are of NK lineage [2]. ENKTL commonly affects adult males and is prevalent in Asia, Mexico, Central or South America but relatively little is known about the precise etiology of this tumor. The strong ethnic predilection seems to suggest a role for the immunogenetic background and environmental factors while the clear association with $\mathrm{EBV}$, irrespective of the ethnic origin of the patients, indicates an important role of the virus in the pathogenesis of the disease [1]. The EBV exists in a clonal episomal form in the tumor cells and shows a type II latency pattern [3]. It is usually of subtype A, with a high frequency of 30-base-pair deletion of the Latent Membrane Protein-1 (LMP-1) gene [4,5]. Histologically, the tumor is characterized by diffuse lymphoid infiltration with angiodestructive growth pattern and prominent necrosis. Phenotypically, the neoplastic cells express cCD3; CD2; CD56; cytotoxic markers, such as TIA1, granzyme B and perforin; and EBV. Based on the current WHO classification criteria, the diagnosis of ENKTL requires the expression of cCD3, cytotoxic markers and Epstein-Barr virus encoded RNA (EBER) by in situ hybridization [1].

ENKTL remains a challenging disease to study and the obstacles are mainly a result of the rarity of this disease and limited tissue availability due to prominent necrosis [6]. Furthermore, the distinction of ENKTL from other EBV-associated cytotoxic T- and NK-cell lymphoproliferative diseases, such as ANKL, chronic active EBV infection, systemic EBV-positive T-cell lymphoma, and primary nodal EBV-positive peripheral T-cell lymphoma not otherwise specified (PTCL NOS) can be challenging due to significant overlap in morphology and phenotype [7,8]. The distinction of ENKTL from these closely related entities is heavily dependent on the age at presentation, sites of involvement and $\mathrm{T}$ vs. NK-cell lineage. However, as there is no absolutely specific marker for NK-cell origin [2], the diagnosis of an NK-cell malignancy is often dependent on the exclusion of other T-cell derived neoplasm. Moreover, the earlier studies on ENKTL suffered from incomplete workup to distinguish between T vs. NK cell lineage of the cases analyzed, making data interpretation difficult. In addition to the diagnostic challenges, ENKTL is also an aggressive disease in need of more effective treatment modalities. ENKTLs express high levels of the drug exporter p-glycoprotein and, hence, have a poor sensitivity to anthracycline-based chemotherapy [9]. The current standard of care for ENKTL is L-asparaginase based combination chemotherapy with or without radiotherapy. However, outcomes remain poor with a five-year survival of $50 \%$ at best for patients with advanced stage disease [10]. Therefore, there is an urgent clinical need to identify effective targeted therapy for this disease.

Molecular profiling is playing an increasingly important role in the diagnosis and classification of lymphomas. The utility of gene expression profiling (GEP) to identify distinct subtypes of diffuse large B-cell lymphoma based on cell of origin is a key example [11]. In terms of guiding management, the presence of the 17p deletion or TP53 mutations are crucial in chronic lymphocytic leukemia [12]. The genomics of T- and NK-cell malignancies have been an active field of research in the recent years. The identification of Ten eleven translocation -2 (TET2), Isocitrate Dehydrogenase (IDH) and DNA methyl transferase 3A (DNMT3A) mutations in peripheral T-cell lymphoma has been a major advance [13-15]. In a similar vein, the identification of unique gene expression profiles and dysregulated signaling pathways in ENKTL is providing new insight into the pathogenesis of this disease $[6,16]$. Despite this progress, current knowledge of the ENKTL genome has yet to produce a meaningful impact on clinical practice. In this review, we aim to highlight the key players in the molecular biology and genetic make-up of ENKTL, with a focus on those with the greatest translational potential.

\section{Insights from Gene Expression Profiling}

\subsection{Classification}

In addition to the delineation of pathways underlying lymphomagenesis, GEP studies have provided new perspectives on the molecular biology, ontogeny and classification of PTCL, including 
ENKTL. The gene expression profiles of ENKTL cluster together irrespective of NK- or cytotoxic T-cell lineage, supporting the current WHO classification to include tumors of these two lineages in the same lymphoma category [17]. However, the number of cases analyzed is limited [17] and other GEP studies included either mostly ENKTL of NK-cell origin or lacks complete data regarding T vs. NK-cell lineage [18-20].

The gene expression profile of ENKTL is distinct from that of PTCL, NOS [17,19] and enriched in genes related to NK-cell activation/survival and NK-cell markers, including Cluster differentiation 244 (CD244), FAS Ligand (FASLG), Killer Immunoglobulin Receptor 2DL4 (KIR2DL4), Killer cell lectin like receptor subfamily D1 (KLRD1), SH2 Domain containing protein 1B (SH2D1B), Killer cell lectin like receptor subfamily C2 (KLRC2) and Neural Cell Adhesion Molecule 1 (NCAM1) [21]. Iqbal et al. utilized a molecular classifier based on 84 transcripts, which was able to identify lymphomas originating from NK cells as well as a subset of gamma-delta $(\gamma \delta)$ T cells with a very similar molecular signature to NK cells. These $\gamma \delta$ PTCLs are non-hepatosplenic in presentation and may be molecularly akin to a subset of ENKTL with $\gamma \delta$ T-cell origin, a reflection of the related ontogeny [19]. Using a similar set of transcripts, the authors subsequently demonstrated that the molecular classifier was able to identify 97\% (31/32) of ENKTL cases and reclassified 9\% (13/150) of PTCL-NOS as ENKTL [18,21]. These cases could then be classified as ENKTL or $\gamma \delta$-PTCL, the latter subgroup showing a high expression of cluster differentiation 3 gamma delta $(\mathrm{CD} 3 \gamma \delta)$ and cluster differentiation 3 delta $(\mathrm{CD} 3 \delta)$ mRNA as well as transcripts encoding T-cell receptor-gamma (TCR $\gamma$ ) chain. Overall, the classifier for ENKTL is highly specific and the signature for ENKTL is largely shared by tumors of the innate immune system, i.e., NK cells and $\gamma \delta$ T cells. The subset of PTCL-NOS belonging to $\gamma \delta$ T-cell lymphomas by molecular classification showed clinical outcome similar to ENKTL [19,21].

Using GEP and copy number analysis, it has recently been demonstrated that not all EBV-positive T/NK-cell lymphomas in adults should be classified as ENKTL. Cases presenting with nodal disease are characterized by unique clinicopathologic features, such as old age, lack of nasal involvement, T-cell origin, CD8-positive/CD56-negative phenotype as well as distinctive molecular and copy number signatures, such as the loss of 14q11.2, which correlates with T-cell origin. Since the 14q11.2 locus contains the T-cell receptor alpha constant (TRAC), the loss of 14q11.2 in the nodal cases is likely a reflection of the physiologic rearrangement of the TCR loci as focal loss within the TCR loci can occur during VDJ recombination. Taken together, these features support a distinct molecular biology and suggest that cases presenting with primary nodal disease should be classified separately from ENKTL [22]. This distinction is clinically important as the nodal cases (currently termed "EBV-positive PTCL NOS") is significantly more aggressive than ENKTL and should be managed differently [22,23]. Other than EBV-positive primary nodal T/NK cell lymphomas, ENKTL also shows significant clinicopathologic and diagnostic overlap with the spectrum of EBV-associated T/NK-cell lymphoproliferative diseases occurring in childhood (TNKLPDC), such as systemic EBV-positive T-cell lymphoma, ANKL and chronic active EBV infection of T/NK cell type [24,25]. Gene set enrichment analysis revealed similarities and subtle differences between TNKLPDC and ENKTL with the former showing a distinctive enrichment of stem cell related genes while ENKTL is enriched for genes over-expressed in advanced solid cancers [26]. This finding of potential cancer stem cell properties in TNKPLDC may have therapeutic implications and may also explain the success of hematopoietic stem cell transplant (HSCT) in the treatment of TNKLPDC and why conventional chemotherapy, without HSCT, is often unsuccessful.

\subsection{Deregulated Single Genes}

\subsubsection{Survivin}

Survivin belongs to the family of inhibitor of apoptosis proteins, which function to inhibit caspase activation, thereby leading to negative regulation of apoptosis or programmed cell death [27]. $\mathrm{Ng}$ and colleagues found overexpression of survivin in 97\% of ENKTL cases [20]. The effect of survivin 
upregulation is that of a pro-survival cellular phenotype, and therefore overexpression of survivin may account for the relative resistance of this tumor to anti-cancer therapy. In vitro studies using a survivin inhibitor, terameprocol, led to a significant increase in apoptosis and decreased viability of tumor cells, thus presenting a potential therapeutic opportunity.

\subsubsection{AURKA}

Aurora Kinase A (AURKA) is a serine/threonine kinase that contributes to the regulation of cell cycle progression. High level of AURKA mRNA expression was found in ENKTL patient samples and cell lines $[19,20]$, along with protein detection by immunohistochemistry. AURKA is located at a frequently $(>50 \%$ ) amplified locus in lymphomas derived from ENKTL $[18,19]$. The main cellular role of AURKA is in promoting mitosis [28], however it has recently been implicated to play a part in cell proliferation through MYC and WNT signaling, whilst inhibiting TP53 [29-31]. Novel small molecule AURKA inhibitor (MK-8745) in NK-cell lines revealed a significant increase in apoptosis and cell cycle arrest suggesting a potential avenue for therapeutic targeting [19]. Furthermore, AURKA overexpression predicts resistance to taxane chemotherapy and AURKA inhibition has been shown to sensitize tumors to paclitaxel [28].

\subsubsection{C-MYC}

C-myc, a transcriptional target of the EBV proteins, EBNA and LMP1, appears to play a considerable role in the transcriptional deregulation of ENKTL [32]. In addition to a potential role in global microRNA repression (see below), several Myc-induced transcriptional targets, such as EZH2 and RUNX3, have been reported to be upregulated in ENKTL. Although therapeutic strategies targeting MYC are being investigated in other lymphomas, they are yet to be explored in ENKTL [33].

\subsubsection{EZH2}

Myc-induced downregulation of the microRNAs miR-26a and miR-101 leads to upregulation of their target Enhancer of Zeste Homolog 2 (EZH2) in ENKTL tumor tissue and cell lines [34]. EZH2 is a H3K27-specific histone methyltransferase and a component of the polycomb repressive complex 2 (PRC2), involved in the epigenetic maintenance of repressive chromatin marks [35]. Recent studies have shown that EZH2 can also function as a transcriptional co-activator via a non-canonical pathway, which has been shown to be the mechanism by which EZH2 promotes cell growth in ENKTL cells [36]. Phosphorylation of EZH2 by JAK3 mediates this switch from histone methyltransferase to transcriptional co-activator, resulting in the upregulation of a set of genes that are involved in DNA replication, cell cycle, biosynthesis, stemness and invasiveness [34,36]. Of note, a JAK3 inhibitor was able to significantly reduce the growth of ENKTL cells in vitro, thereby providing a potential pathway for the development of novel therapeutics. EZH2 inhibitors are being investigated in clinical trials for B-cell lymphomas, however their clinical efficacy is yet to be assessed in ENKTL [37].

\subsubsection{RUNX3}

Runt-domain transcription factor 3 (RUNX3), a master transcriptional regulator in major developmental pathways, is another gene that is positively regulated by C-MYC [38]. RUNX3 can function as either a tumor suppressor or oncogene, depending on tumor type [39]. In cytotoxic $T$ and NK cells, it has been shown to mediate transcriptional activation of genes involved in lymphocyte activation, proliferation, and effector function, which include interferon gamma (IFN-gamma) perforin and granzyme B [40]. RUNX3 expression is upregulated in ENKTL, as well as in the majority of high-grade B-cell lymphomas and peripheral T-cell lymphomas [38]. SiRNA -induced silencing of RUNX3 resulted in increased apoptosis and reduced cell proliferation in ENKTL cell lines, suggesting an oncogenic role for RUNX3 in ENKTL. Inhibition of MYC by a novel small molecule inhibitor, JQ1, resulted in downregulation of RUNX3 transcripts [38]. The precise mechanism of RUNX3-mediated reduction in cellular proliferation and increased apoptosis remains to be further delineated. 
Among the deregulated single genes described above, EZH2, Survivin and AURKA have promising translational impact and may serve as potential therapeutic targets. In particular, JAK3 inhibition appears to be an attractive therapeutic approach and evaluation of JAK3 inhibitors as modulators of non-canonical EZH2 activity in clinical trials is warranted.

\subsection{Deregulated Signaling Pathways}

\subsubsection{JAK/STAT}

Several studies have provided evidence supporting a role for the Janus Kinase/Signal Transducer and Activator of Transcription (JAK/STAT) pathway in ENKTL lymphomagenesis [41]. Gene expression profiling has shown that members of the JAK/STAT pathway are differentially expressed in ENKTL tumor cells compared to normal NK cells [17,42]. Whilst the frequency of JAK3 activating mutation in ENKTL appears to vary across studies in different ethnic populations $(0-35 \%)$ [ $43-46$ ], JAK3 phosphorylation is detected in $87 \%$ of the tested tumors and about $20 \%$ of cases is a result of activating mutations in the pseudo kinase domain of JAK3 [46], indicating that the constitutive activation of JAK3 pathway in ENKTL can arise from mechanisms other than mutation.

\subsubsection{PDGF pathway}

Platelet derived growth factor receptor alpha (PDGFR $\alpha$ ) is a receptor tyrosine kinase mediating important cell functions such as migration, proliferation, and cell survival and known to interact with PI3K/AKT and STAT signaling pathways [47]. PDGFR $\alpha$ gene and protein, including its phosphorylated form, is overexpressed in ENKTL, indicating activation of this pathway [17]. The tyrosine kinase inhibitor, imatinib mesylate, induced concentration-dependent growth inhibition in a PDGFR $\alpha$-expressing ENKTL cell line, MEC04 [17]. The cause of PDGFRA deregulation in ENKTL remains uncertain and is not a result of genomic imbalances, gene mutations or overrepresentation of the $\mathrm{H} 2 \alpha$ haplotype, the latter is known to result in up-regulation of PDGFRA in glioblastoma [17].

\subsubsection{NOTCH-1}

The NOTCH signaling pathway is a highly conserved pathway with key roles in a wide variety of developmental processes and cancer. Studies have shown an enrichment of genes in the NOTCH signaling pathway in ENKTL $[17,19]$. Two NOTCH inhibitors, which are potent inhibitors of $\gamma$-secretase and Notch processing, induced significant growth inhibition in two NK-cell lines, providing preliminary evidence for the potential therapeutic targeting of this pathway [19]. However, these agents are yet to be evaluated in clinical trials.

\subsubsection{NF-kB}

The relevance of the NF- $\kappa B$ pathway in ENKTL has been highlighted in two GEP studies, which found significant enrichment of genes in this pathway in ENKTL $[17,20]$. However, a separate study did not confirm the same findings [19]. Further research is therefore required to investigate the overall significance of NF-kB pathway in ENKTL. Although targeting NF- $\mathrm{kB}$ through bortezomib-based combinations has been attempted in ENKTL, data are only available on small cohorts of patients and larger trials are required for a more comprehensive assessment of efficacy and safety $[48,49]$.

\subsubsection{Other Signaling Pathways}

The VEGFR and AKT signaling pathways may also play a role in the pathogenesis of ENKTL $[6,50]$. The VEGFR inhibitor, bevacizumab, has been investigated in combination with cyclophosphamide, doxorubicin, vincristine, prednisolone (CHOP) in a small, heterogeneous group of patients with T-cell lymphomas [51]. The number of ENKTL patients was small and they were analysed together with PTCL patients. The overall response rate was 53\%, suggesting a modest efficacy. ENKTL are known to have a poor response to anthracycline-based therapy, therefore clinical trials evaluating this agent 
in combination with L-asparaginase based regimens may be of value. AKT inhibitors are also under evaluation in clinical trials of unselected patients with relapsed lymphoma but their clinical efficacy in ENKTL remains to be established [52].

Among the pathways discussed, JAK/STAT and NF- $\mathrm{KB}$ are the best studied in ENKTL. The drugs targeting these pathways have made significant progress in terms of clinical development and have the greatest translational potential in the future.

\section{Insights from Copy Number Analysis}

Although no genetic abnormalities specific to ENKTL has been identified, studies based on comparative genomic hybridization $(\mathrm{CGH})$ and loss of heterozygosity $(\mathrm{LOH})$ analyses have identified recurrent gains and losses mapping to several chromosomal regions [17,18,53-57] (Figure 1 and Table S1), with one study finding up to 177 recurrent chromosomal gains and 35 losses [57].
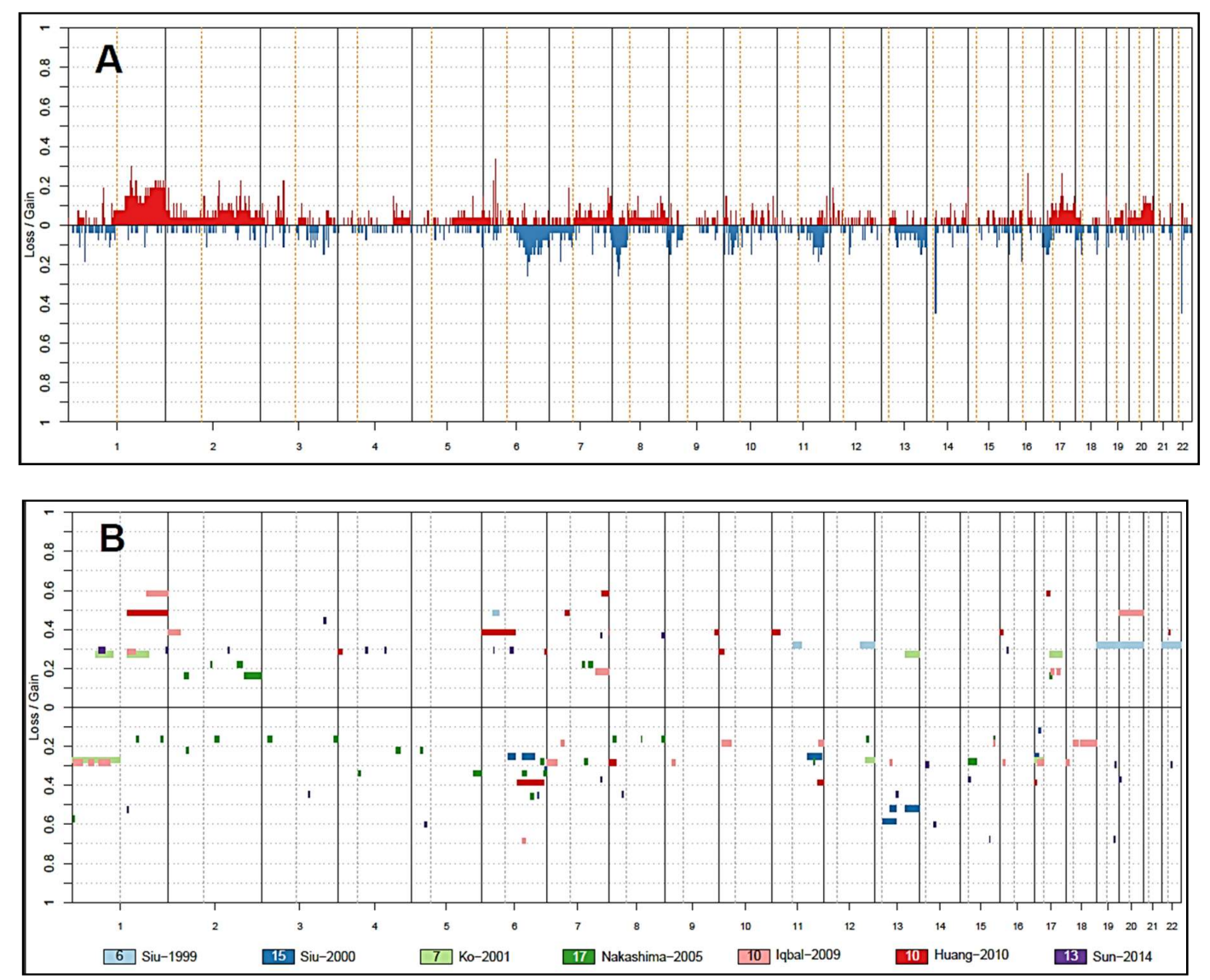

Figure 1. Penetrance plots of copy number aberrations (CNA) of ENKTL in comparison with published literature. Orange vertical line indicates centromere position. $Y$-axis indicates frequency of CNA. (A) Penetrance plots of 29 cases of ENKTL tested using Oncoscan molecular inversion probe assay [22]; (B) summary of recurrent CNA in previously published data. Recurrent CNA defined as aberrations occurring in two or more samples in each study (Table S1B). Number of samples in each study is indicated in the colour boxes.

\subsection{Copy Number Loss (Potential Tumor Suppressor Genes)}

The most consistently detected chromosomal abnormality among the studies to date is deletion of chromosome 6q, in particular 6q21-25. Sun et al. tried to define a minimal tumor suppressor gene-containing region involved in del6q25 through loss of heterozygosity ( $\mathrm{LOH}$ ) and homozygosity mapping of deletion analyses, followed by quantitative multiplex polymerase chain reaction analysis 
on 37 nasal and nasal-type NK/T-cell lymphoma patients using a panel of 25 microsatellite markers, covering the 6q21-q25 region and identified a $2.6 \mathrm{Mb}$ interval located between TIAM2 and SNX9 genes [58]. Subsequent development of array CGH has allowed better resolution and identification of the specific region. The data from gene expression studies supporting a tumor suppressor role for several candidate genes identified within the commonly deleted 6q21 region are summarized below. Most of the available evidence is correlative and supplemented by preliminary in vitro functional studies in ENKTL cell lines.

\subsubsection{PRDM1}

PRDM1 encodes the transcription factor Blimp-1, which is a multi-functional master regulator of plasma cell differentiation [59], its role in ENKTL has been examined by several groups. Iqbal and colleagues found generally low expression of PRDM1 in ENKTL [18]. In addition to 6q21 deletion, they also detected mutations resulting in truncated forms of PRDM1. A further mechanism for the low expression of PRDM1 (presumably for 6q21 intact cases) is methylation of CpG islands $5^{\prime}$ of the PRDM1 gene; highly methylated $\mathrm{CPG}$ islands $5^{\prime}$ of PRDM1 correlated with low expression of the transcripts, and reversal of methylation by Decitabine induced expression of PRDM1 with accompanying cell death $[18,60]$. Interestingly, another study found discrepant results in PRDM1 mRNA levels (which were under-expressed in cell lines but increased in a subset of primary tumors), independent of the presence or absence of $6 \mathrm{q} 21$ deletion [17]. Moreover, $\mathrm{Ng}$ et al. found overexpression of BLIMP1 protein by immunohistochemistry in ENKTL tumor tissue [32]. In view of these discrepancies, further studies are required to clarify the true significance of PRDM1 in the pathogenesis of ENKTL.

Interestingly, it has been shown that PRDM1 expression in ENKTL tumor samples may be of prognostic significance with positive expression being associated with longer progression free and overall survival [61]. In cases with negative staining of PRDM1, transcripts of PRDM1 were still detected, suggesting a possible post-transcriptional regulation at play, such as one mediated by miR-223 (see below).

\subsubsection{HACE1}

HACE1 encodes a novel E3 ubiquitin ligase, which has been proposed as a tumor suppressor gene in multiple human cancers, including Wilm's tumor [62]. HACE1-/- mice are spontaneously prone to developing multiple malignant tumors in various organs. It was found to be significantly downregulated in ENKTL through a combination of monoallelic 6q21 deletion and cytosine phosphate guanine $(\mathrm{CpG})$ island methylation $[17,63]$, but functional studies have yet to conclusively establish the role of HACE1 in the pathogenesis of ENKTL $[64,65]$.

\subsubsection{PTPRK}

PTPRK encodes receptor-type tyrosine-protein phosphatase $k$, the only protein tyrosine phosphatase (PTPase) among the 3 PTPases located on chromosome 6q21 that interacts with STAT3. Chen et al. demonstrated that the loss of PTPRK expression due to monoallelic deletions and aberrant promoter hypermethylation likely contributes to lymphomagenesis by activating the STAT3 oncoprotein in ENKTL cells [66]. Furthermore, in their study of 27 patients with ENKTL, the authors found that underexpression of PTPRK protein in tumor cells correlated with advanced-stage disease, and that PTPRK promoter hypermethylation in tumors possibly correlated with a poorer prognosis in 17 patients treated with the steroid, methotrexate, iphosphamide, L-asparaginase, etoposide (SMILE) protocol [66]. As methylation of the PTPRK promoter can be reversed by demethylating agent, 5-aza-dC, epigenetic therapy may be able to target PTPRK-mediated cell signaling in ENKTL [66].

\subsubsection{Other Candidate Genes in the Commonly Deleted 6q21 Region}

ATG5 is a protein involved in the autophagy pathway as well as apoptosis [67]. Low expression of ATG5 in ENKTL was found in two studies $[17,18]$. However, the role of ATG5 in the pathogenesis 
of ENKTL remains controversial given its role in tumorigenesis and tumor suppression in other malignancies [40]. AIM1 is an actin-binding protein that suppresses cell migration [68] and is underexpressed in ENKTL $[17,18]$. Similar to PRDM1, highly methylated CpG islands $5^{\prime}$ of AIM1 correlated with low expression of the transcripts [18]. FOXO3 is a member of the forkhead family of proteins. Re-expression of FOXO3 suppressed the proliferation of an NK-cell line with haploinsufficiency as the suggested mechanism responsible for FOXO3 inactivation in ENKTL [69]. Further work is however required to evaluate the functional role of this protein in ENKTL.

In summary, PRDM1 remains the best evaluated putative tumor suppressor gene in ENKTL. Nonetheless, restoring the function of an inactivated tumor suppressor gene remains more challenging than inhibiting a hyperactivated oncogene. Hence, development of clinically useful strategies in this field remains a work in progress. Epigenetic silencing of PRDM1 and PTPRK using hypomethylating agents, however, may be an attractive therapeutic option for ENTKL.

\subsection{Other Chromosomal Gains and Losses}

Other less well-characterized genomic alterations include gains at chromosome 1q, 2q, 6p, 7q, $17 q$, and $20 q$, and losses at 11q, 13q and 17p. Gene expression analyses showed that among the gains, the majority of genes showing more than two-fold-overexpression play a role in cell proliferation, cell cycle progression and metabolic processes. There was downregulation of major functional groups of genes within the most frequently lost regions, including genes involved in transcriptional repression (NCOR1, PRDM1a and ZNF10), and tumor suppressors (FOX01A, CHFR, CDKN2C and $M A P 2 K 4)[17,18]$. Negative regulators of the cell cycle and cytoskeletal organization (KIF2C, MCM10 and MAD2L2) and pro-apoptotic genes, such as P53AIP1, PRKACB, DFFA and SH3GLB1, were also downregulated $[17,18]$.

Two findings stand out particularly among the chromosomal abnormalities found outside the 6q21-25 region in terms of their clinical relevance. Sun et al. found that six out of thirteen patients with ENKTL had a previously unreported recurrent loss of $8 \mathrm{p} 11.23$, which correlated with a significantly worse prognosis compared to patients without this loss [57]. Although the authors postulate ADAM3A as a candidate gene at this locus, its definitive role has yet to be established.

In a recent study of 12 EBV-positive PTCL and 29 ENKTL using the Oncoscan-molecular inversion probe array, $\mathrm{Ng}$ et al. highlighted that loss of $14 \mathrm{q} 11.2$ is present in the majority of EBV-positive PTCL and in a subset of ENKTL. Loss of 14q11.2 correlates with T-cell origin in their study samples and may be a potentially useful marker of T-cell lineage [22].

\section{Insights from Genome Wide Association Studies}

ENKTL is prevalent among Asians and the indigenous populations of Mexico, Central and South America, suggesting that the risk of developing the disease depends on both immunogenetic background and environmental factors [70]. However, the molecular and genetic mechanisms underpinning individual susceptibility are poorly understood. Thus far, there have been two major studies investigating the genetic risk of ENKTL.

Based on previous observations that several cytotoxic T-lymphocyte (CTL) defined epitopes were mapped to EBV latent membrane proteins (LMPs) restricted with HLA-A2, -A11 or -A24 antigens, Kanno and colleagues performed a HLA-A allotyping study in 25 patients with ENKTL compared with 303 healthy controls of Japanese descent and reported significantly lower frequency of the HLA-A*0201 allele in ENKTL [71]. The authors therefore suggested that the HLA-A*0201-restricted CTL responses to LMPs in EBV-infected pre-neoplastic and/or neoplastic cells of NK-cell lineage may function in vivo to suppress the development of overt lymphoma, raising the possibility of the development of immune therapy.

A subsequent first genome-wide association study (GWAS) of 189 extranodal ENKTL and 957 controls of Chinese descent by $\mathrm{Li}$ et al. did not reveal a similar finding of lower frequency of HLA-A*0201 in their study population [72]. Instead, the authors showed that the single nucleotide 
polymorphism (SNP) rs9277378 (located in HLA-DPB1) had the strongest association with ENKTL $\left(p=4.21 \times 10^{-19}\right)$. HLA-DPB1 is the $\beta 1$ subunit of the HLA-DP heterodimer involved in extracellular antigen presentation to CD4-positive T-cell lymphocytes [73]. This finding thereby highlights the importance of HLA-DP antigen presentation in the pathogenesis of ENKTL. The study did not find an association between HLA-DPB1 and other EBV-related malignancies, such as nasopharyngeal carcinoma in southern Chinese populations and Hodgkin's lymphoma in Europeans from publicly available GWAS results, suggesting that these diseases might have distinct molecular mechanisms of pathogenesis beyond EBV infection.

Interestingly, $\mathrm{Li}$ and colleagues also found that, in the discovery cohort, the association between the HLA-DPB1 rs9277378*A risk allele and increased risk of ENKTL was much stronger in patients without hepatitis B virus (HBV) infection, compared with patients who had concurrent HBV infection. As the HLA-DPB1 rs9277535*A risk allele was previously reported to be associated with improved clearance of HBV [74], the authors postulate that individuals with greater HBV clearance ability would have a higher risk of ENKTL. Indeed, in a recent case control study including 417 ENKTL cases and 488 age- and sex-matched controls, individuals who were naturally immune to HBV were significantly more likely to be diagnosed with ENKTL $(p=0.001)$ [75].

These findings all suggest that SNPs associated with host immunity and inflammatory responses, including to HBV, play an important role in the individual susceptibility and subsequent development of ENKTL. Determining the precise mechanisms underlying these associations could be relevant to the development of personalized and successful immunotherapies.

\section{Insights from Mutational Profiling}

Several studies have focused on elucidating the mutational landscape of ENKTL (Figure 2, Table 1, and Table S2). The genes are related to the various important pathways mentioned above, including JAK-STAT-pathway members, epigenetic modifiers, nucleoside binding, biological adhesion and plasma membrane, RNA helicases and tumor suppressors, indicating that abnormalities of these biological functions and processes may have substantial roles in tumor pathogenesis. NK- and T-cell derived ENKTL as defined by TCR gene rearrangement assays showed no significant differences in their mutational landscape [76].

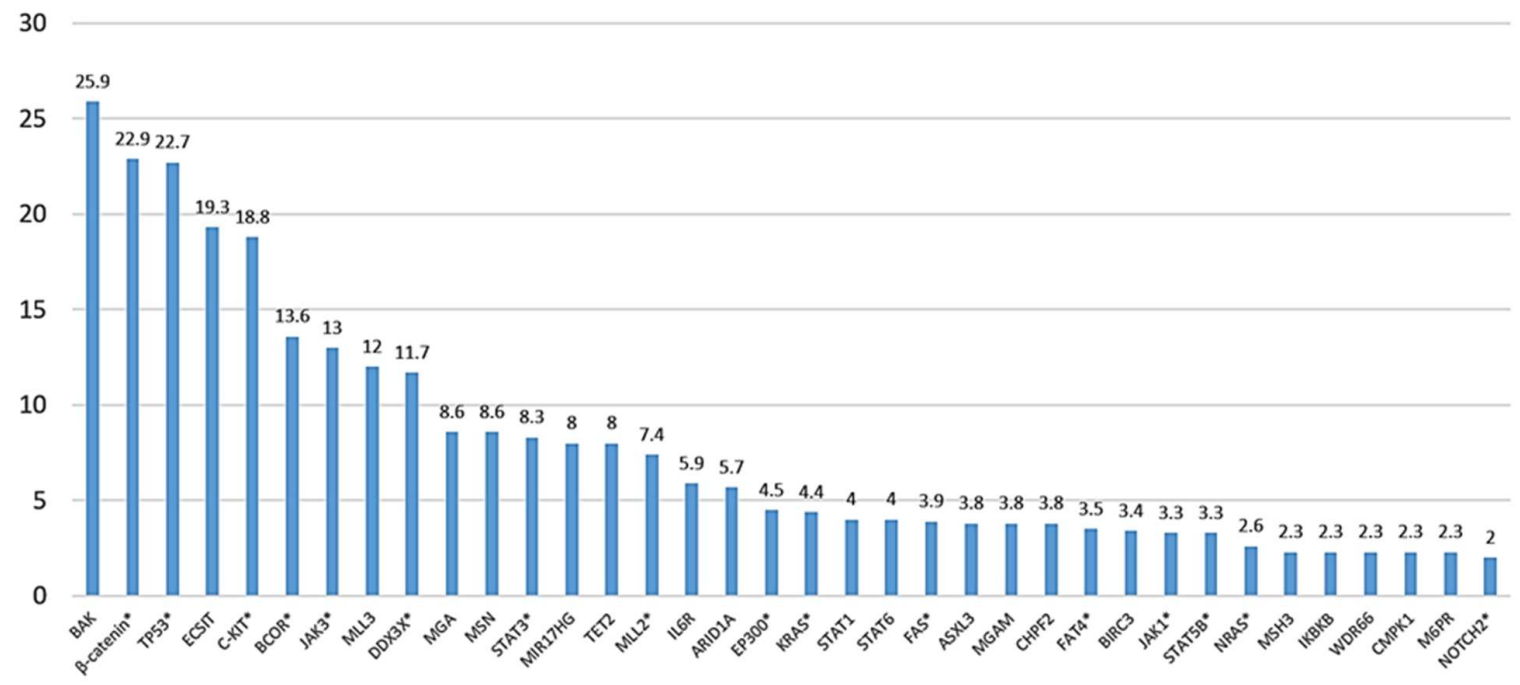

Figure 2. Overall frequency of somatic gene mutations identified in ENKTL. Y-axis indicates percentages. Overall frequency calculated based on total number of cases reported in each study (refer Table S2 for details). Mutations identified in two or more studies are highlighted with *. 
Table 1. Summary of the frequency of recurrent mutations in ENKTL. The overall frequency of mutations is expressed as a percentage of mutated cases out of the total number of cases tested. The reported frequency is available for comparison. Mutations reported in two or more studies are highlighted in bold. See Table S2 for further details.

\begin{tabular}{|c|c|c|c|}
\hline Gene & Reported Frequency & $\begin{array}{c}\text { No. of Positive Cases } \\
\text { (Total No. of Cases Tested) }\end{array}$ & Overall Frequency (\%) \\
\hline ARID1A & 6 & $6(105)$ & 5.7 \\
\hline ASXL3 & 4 & $4(105)$ & 3.8 \\
\hline$B C O R$ & $6-32$ & 20 (147) & 13.6 \\
\hline$b$-catenin & $16-30$ & $41(179)$ & 22.9 \\
\hline BIRC3 & 3 & $3(88)$ & 3.4 \\
\hline$B A K$ & 25.9 & $7(27)$ & 25.9 \\
\hline CHPF2 & 4 & $4(105)$ & 3.8 \\
\hline$C-K I T$ & $5-52$ & $30(170)$ & 18.8 \\
\hline CMPK1 & 2 & $2(88)$ & 2.3 \\
\hline$D D X 3 X$ & $8-50$ & $33(283)$ & 11.7 \\
\hline ECSIT & 19 & $17(88)$ & 19.3 \\
\hline EP300 & $4-6$ & $7(156)$ & 4.5 \\
\hline FAT4 & $2-8$ & $4(113)$ & 3.5 \\
\hline FAS & 4 & $3(76)$ & 3.9 \\
\hline$I K B K B$ & 2 & $2(88)$ & 2.3 \\
\hline$I L 6 R$ & 6 & $2(34)$ & 5.9 \\
\hline$J A K 1$ & $2-8$ & $3(90)$ & 3.3 \\
\hline JAK3 & $5-35$ & $36(227)$ & 13 \\
\hline KRAS & $3-25$ & $11(251)$ & 4.4 \\
\hline MLL2 & $2-18$ & $14(190)$ & 7.4 \\
\hline MLL3 & 12 & $3(25)$ & 12 \\
\hline MSH3 & 2 & $2(88)$ & 2.3 \\
\hline$M 6 P R$ & 2 & $2(88)$ & 2.3 \\
\hline MIR17HG & 8 & $2(25)$ & 8 \\
\hline$M S N$ & 9 & $9(105)$ & 8.6 \\
\hline$M G A M$ & 4 & $4(105)$ & 3.8 \\
\hline$M G A$ & 9 & $9(105)$ & 8.6 \\
\hline NRAS & $2-25$ & $6(227)$ & 2.6 \\
\hline NOTCH2 & $2-25$ & $3(153)$ & 2 \\
\hline STAT1 & 4 & $1(25)$ & 4 \\
\hline STAT3 & $1-26$ & 30 (387) & 8.3 \\
\hline STAT5B & $2-6$ & $8(244)$ & 3.3 \\
\hline STAT6 & 4 & $1(25)$ & 4 \\
\hline TP53 & $4-63$ & $139(611)$ & 22.7 \\
\hline TET2 & 8 & $2(25)$ & 8 \\
\hline WDR66 & 2 & $2(88)$ & 2.3 \\
\hline
\end{tabular}

\subsection{JAK/STAT Pathway Associated Genes}

JAK3, STAT3 and STAT5B mutations leading to constitutive activation of the JAK/STAT pathway have been found in up to $35 \%$ of cases of ENKTL [42,44,46]. A few studies have found none or a much lower frequency of JAK3 mutations and more frequent JAK3 phosphorylation instead [43,45,76,77], suggesting that alteration of JAK3 function is predominantly attributed to phosphorylation rather than mutation and the variable frequency of occurrence reported may be due to the different detection platforms or a reflection of population/ethnicity-related differences. Similarly, STAT3- and STAT5B-activating mutations are found in only $6 \%$ of cases each [78], while STAT3 phosphorylation activation at Tyr705 is found in about $90 \%$ of cases [17,41]. It has been postulated that since PTPRK normally dephosphorylates phospho-STAT3, under-expression of PTPRK, whose encoding gene is located in the commonly deleted $6 \mathrm{q}$ region, due to deletion or promoter hypermethylation may lead to STAT3 activation [66]. 
In their study, Sim et al. found two novel JAK3H583Y and JAK3G589D somatic mutations which the authors suggested had more oncogenic potential and were also more sensitive to Tofacitinib, a potent inhibitor of JAK1 and JAK3 [77]. The same authors also found that although the frequency of STAT3 mutations was low in patients with ENKTL, STAT3-mutant ENKTL cells were sensitive to the STAT3 inhibitor, Stattic, but not to Tofacitinib. A selective inhibitor of JAK3 (PRN371) has recently been demonstrated to have more potent anti-tumor activity than Tofacitinib in a xenograft model of ENKTL with a JAK3 mutation [79]. These results indicate that JAK3 and STAT3 are candidate therapeutic targets in patients with ENKTL. Phase II clinical trials of Ruxolitinib, a JAK1/2 inhibitor approved for myelofibrosis, are now in progress for patients with relapsed ENKTL [80].

\subsection{Epigenetic Regulators}

BCOR and MLL2 are epigenetic regulators known to be mutated in other malignancies. BCOR interacts with some histone-deacetylase-family genes and MLL2 encodes a histone methyltransferase [81,82]. BCOR and MLL2 mutations are also seen in ENKTL, with apparent mutual exclusivity $[42,76,83]$. While the clinical and biological relevance of these mutations remains unclear, epigenetic modification may play a role in tumor pathogenesis as both genes are involved in chromatin modification. Mutations in other epigenetic modifiers ASXL3, ARID1A and EP300 have also been found at varying frequency [76].

\section{3. $D D X 3 X$}

DDX3X is a RNA helicase gene and mutants exhibit decreased RNA-unwinding activity, loss of suppressive effects on cell-cycle progression in NK cells and transcriptional activation of NF-KB and MAPK pathways [76]. DDX3X mutations are frequent and reported in up to 50\% of ENKTL cases [76,83]. Jiang et al. found that mutations of DDX3X seldom overlap with TP53, suggesting that these two genes may be involved in very closely related biological processes [76].

\subsection{TP53 and Pro-Apoptotic Genes}

TP53 is a crucial tumor suppressor gene known to be mutated in several malignancies [84]. TP53 mutations are present in up to $63 \%$ of cases of ENKTL $[42,76,85-88]$. They have been associated with advanced stage disease, suggesting that TP53 mutation represents a secondary rather than an initiating oncogenic event in ENKTL [89]. Indeed, Jiang et al. demonstrated that individuals with mutations in DDX3X and TP53 had much worse clinical prognosis than individuals without mutations in these two genes [76]. Nevertheless, TP53 is found under-expressed in ENKTL transcriptomic analyses, and the observation that EBNA1 promotes TP53 degradation has to be taken into account in the consideration of TP53 pathway as a possible target for ENKTL therapy [50]. Failure of apoptosis in ENTKL due to TP53 mutations may be enhanced by mutations in apoptotic protein FAS [90]. The precise mechanisms involved require further evaluation.

\subsection{ECSIT}

ECSIT has been identified as a cytoplasmic protein involved in Toll-like receptor (TLR), transforming growth factor beta/bone morphogenetic protein (TGF- $\beta$ /BMP) signaling pathways, and has been shown to play an important role in TLR4-mediated signals to activate NF- $\mathrm{BB}$ [91]. In line with published data, the ECSIT-T419C mutation activates the NF-KB pathway in ENKTL and induces secretion of proinflammatory cytokines. Wen and colleagues recently identified a hotspot mutation encoding ECSIT-V140A in 19.3\% of 88 ENTKL cases. This mutation was associated with younger age, advanced clinical stage, high International Prognostic Index (IPI), splenomegaly, presence of hemophagocytic syndrome (HPS) and poor prognosis [92]. Preliminary data on two ENKTL patients expressing ECSIT-V140A revealed that a combination of thalidomide and dexamethasone was effective in reversing the HPS. Additional studies are necessary to determine the frequency and role of the 
ECSIT-V140A mutation and the efficacy of the proposed regimen in ENKTL patients expressing this mutation.

\subsection{Pro-Survival Signaling Pathways}

The KIT proto-oncogene encodes a receptor tyrosine kinase which plays an important role in normal hematopoiesis, gametogenesis and melanogenesis. KIT mutations are well-known in the oncogenesis of gastrointestinal stromal tumors and mastocytosis, and tyrosine kinase inhibitors have proven useful in the treatment of these diseases [93]. KIT mutation is reported in up to 52\% of ENKTL cases but a gain of function as a result of the mutations has not been shown [94]. Mutations in RAS family genes (KRAS, NRAS) $[42,76,83,86,95]$, as well as the beta-catenin pathway (CTNNB1) have also been described in ENTKL [86,95].

\section{Epigenetic Dysregulation in ENKTL}

\subsection{Dysregulated Promoter Methylation}

The epigenetic mechanisms underpinning genetic dysregulation in ENKTL are beginning to be understood. On a global level, there appears to be widespread promoter hypermethylation in most ENKTL compared to normal NK cells, assessed in a study using methyl-sensitive cut counting and reduced representation bisulfite sequencing on 12 ENKTL cases and seven NK cell lines [96]. Promoter hypermethylation was especially prominent at "poised genes", which are genes showing histone marks associated with both activated and repressed states. Several known tumor suppressor genes, including BCL2L11 (BIM), DAPK1, PTPN6 (SHP1), TET2, SOCS6, and ASNS show reduced gene expression correlating with promoter hypermethylation in NK cell lines [96]. Ectopic expression of BIM and SOCS6 in non-expressing NK cell lines resulted in growth inhibition and sensitization to chemotherapy-induced apoptosis for BIM, whilst lack of ASNS expression in NK cell lines was associated with increased sensitivity to L-asparaginase treatment. These findings suggest a potential role for methylation markers in guiding therapeutic strategies in ENKTL [96].

Methylation of other putative tumor suppressor genes was also found in an earlier study by Siu LL et al. (2002), in which the promoter methylation status of five putative tumor suppressor genes ( $p 15$, $p 16, p 73, h M L H 1$ and $R A R \beta$ ) was assessed by methylation-specific polymerase chain reaction (MSP) in 33 patients samples using a candidate gene approach [56]. The $p 73$ gene in particular, was methylated in a large majority (94\%) of the cases, and its demethylation with 5-azacytidine resulted in re-induction of gene expression in vitro. Other methylated genes included $h M L H 1(63 \%), p 16(63 \%), p 15(48 \%)$, and $R A R \beta(47 \%)$. Interestingly, MSP identified two cases of occult marrow involvement and detected tumor involvement in a histologically negative oropharyngeal biopsy, suggesting methylation testing to be of potential diagnostic utility.

Other tumor suppressor genes with methylated promoters have been described above, including PRDM1 [18], AIM1 [18], HACE [17,63] and miR-146a [97].

\subsection{MicroRNA deregulation in ENKTL}

In the past two decades, microRNAs, a class of short, $\sim 22$ nucleotide-long non-coding RNAs have been shown to mediate an additional layer of regulatory complexity in gene expression [98]. Most microRNAs negatively regulate the expression their target genes. The role of microRNAs in ENKTL have been recently reviewed [99-101]. On a global level, miRNAs in ENKTL are predominantly down regulated compared to normal NK cells and they include miR-150, miR-101, miR-26a, miR-26b, miR-28-5, miR-363, and miR-146 [32,102]. Upregulated predicted targets are enriched for genes involved in cell-cycle related, p53 and MAPK signaling pathways. Several of the predicted targets, including MUM1, BLIMP1, and STMN1 were verified by immunohistochemistry to be overexpressed in ENKTL tumors [32]. On the other hand, a few microRNAs, such as mir-21 and miR-155 have been shown to be overexpressed in ENKTL, with pro-oncogenic consequences [32,103]. Some microRNAs 
have also been shown to be of prognostic significance. Low expression of miR-146a in ENKTL was associated with a poorer prognosis [97]. Another study reported that elevated plasma levels of miR-221 in ENKTL patients was associated with shorter overall survival and may serve as an adverse prognostic marker [104]. The evidence supporting a role for specific microRNAs in ENKTL lymphomagenesis is summarized in Table 2.

Table 2. Micro RNA deregulation in ENKTL. This table summarizes the mechanisms by which miRNA deregulation leads to lymphomagenesis in ENKTL.

\begin{tabular}{|c|c|c|}
\hline MicroRNA & Evidence Supporting Their Biological Significance & References \\
\hline \multicolumn{3}{|c|}{ MicroRNAs underexpressed in ENKTL } \\
\hline miR-146a & $\begin{array}{l}\text { Overexpression of mir-146a suppressed cell proliferation, induced apoptosis, } \\
\text { and enhanced chemosensitivity by inhibiting the NF-kB pathway via targeted } \\
\text { downregulation of TRAF6. } \\
\text { ENKTL patients with low miRNA-146a expression had higher frequency of } \\
\text { non-response to chemotherapy. }\end{array}$ & $\begin{array}{l}\text { Paik et al. } 2011 \\
\text { [97] }\end{array}$ \\
\hline miR-150 & $\begin{array}{l}\text { MiR-150 is expressed at lower levels in both ENKTL cell lines and tumor tissue } \\
\text { compared to normal NK cells. } \\
\text { Its aberrant downregulation induced continuous activation of the PI3K-AKT } \\
\text { pathway, leading to telomerase activation and immortalization of cancer cells. }\end{array}$ & $\begin{array}{l}\text { Watanabe et al. } \\
2011 \text { [105] }\end{array}$ \\
\hline $\begin{array}{l}\text { miR-26 and } \\
\text { miR-101 }\end{array}$ & $\begin{array}{l}\text { Downregulation of miR-26a and miR-101 resulted in upregulation of their target } \\
\text { Enhancer of Zeste Homolog } 2 \text { (EZH2) in ENKTL tumor tissue and cell lines. }\end{array}$ & $\begin{array}{l}\text { Yan et al. } 2013 \\
\text { [34] }\end{array}$ \\
\hline $\operatorname{miR}-223$ & $\begin{array}{l}\text { MiR-223 targets PRDM1, a potential tumor suppressor gene in ENKTL: } \\
\text { (i) miR-223 and PRDM1 exhibited inverse patterns of expression in ENKTL tissues } \\
\text { and cell lines; } \\
\text { (ii) PRDM1 was identified as a direct target gene of miR-223 by luciferase assays; } \\
\text { (iii) ectopic expression of miR-223 led to downregulation of the PRDM1 protein } \\
\text { in vitro whereas a decrease in miR-223 restored the level of PRDM1 protein. }\end{array}$ & $\begin{array}{l}\text { Liang et al. } 2014 \\
\text { [61] }\end{array}$ \\
\hline $\begin{array}{l}\text { miR-142-3p and } \\
\text { miR-205 }\end{array}$ & $\begin{array}{l}\text { miR-142-3p and miR-205 are downregulated in ENKTL compared with normal } \\
\text { thymic tissue. } \\
\text { Mir-142-3p targets the proinflammatory cytokine interleukin } 1 \text { alpha (IL1A) and } \\
\text { mir-205 targets the oncogene BCL6 in vitro. }\end{array}$ & $\begin{array}{l}\text { Motsch et al. } \\
2012[102]\end{array}$ \\
\hline $\begin{array}{l}\text { miR-10, miR- } \\
\text { 342-3p }\end{array}$ & $\begin{array}{l}\text { Expression of miR-10a and miR-342-3p, which are downregulated in ENTKL } \\
\text { tissues, is inversely correlated with protein expression of their predicted target } \\
\text { gene, T-lymphoma invasion and metastasis inducing factor } 1 \text { (TIAM1). }\end{array}$ & $\begin{array}{l}\text { Huang et al. } \\
2016[106]\end{array}$ \\
\hline \multicolumn{3}{|c|}{ MicroRNAs overexpressed in ENKTL } \\
\hline $\begin{array}{l}\operatorname{miR}-155 \text { and } \\
\text { miR-21 }\end{array}$ & $\begin{array}{l}\text { MiR-21 and miR-155 are over-expressed in ENKTL samples and cell lines. } \\
\text { Mir-21 downregulates phosphatase and tensin homolog (PTEN) and programmed } \\
\text { cell death } 4 \text { (PDCD4), whilst mir-155 directly targets SHIP1 in ENTKL cell lines. } \\
\text { Both PTEN and SHIP1 are involved in the AKT signaling pathway. }\end{array}$ & $\begin{array}{l}\text { Yamanaka et al. } \\
2009[103]\end{array}$ \\
\hline \multicolumn{3}{|c|}{ EBV-encoded microRNAs } \\
\hline BART9 & $\begin{array}{l}\text { BART9 shows a pro-proliferative effect in two ENKTL cell lines (SNK6 and SNT16) } \\
\text { that is mediated, at least in part by upregulation of LMP-1 levels. }\end{array}$ & $\begin{array}{l}\text { Ramakrishnan } \\
\text { etal. } 2011[107]\end{array}$ \\
\hline
\end{tabular}

\subsection{Mechanisms of microRNA Dysregulation in ENKTL}

The mechanisms underlying the widespread downregulation of miRNAs in ENKTL are beginning to be delineated. MYC, a key transcriptional regulator known to cause extensive repression of miRNA, has been shown to be overexpressed in ENKTL and may thus reprise its global miRNA repressor role in the setting of ENTKL $[32,108]$. EBV may play a role in the deregulation of miRNAs since downregulation of let-7g, let-7a, and let-7c, and up-regulation of miR-155 in ENKTL have been demonstrated in other studies to be regulated by EBV $[109,110]$. In addition, epigenetic deregulation due to promoter methylation has been reported to result in the deregulation of miRNAs in ENKTL, such as miR-146a and miR-124-1 [97,111]. 


\section{Potential Immunotherapeutic Targets in ENKTL}

Programmed cell death-1 (PD-1) inhibition has revolutionized immunotherapy in cancer in the recent past [112]. We have previously performed GEP on 29 ENKTL using FFPE tissues and derived the differentially expressed genes between tumor samples and control tissues [22] (GEO database GSE90597). We observed upregulation of PD-Ligand 1 (PD-L1, also known as CD274) mRNA in tumor compared to control tissues (Table S3). Indeed, PD-L1 expression on ENKTL has been demonstrated by immunohistochemistry [113] while in vitro studies using ENKTL cell lines have also shown that overexpression of LMP1 results in upregulated PD-L1 expression [114]. Interestingly, STAT-3 mutations have been proposed as a mechanism by which ENKTL cells upregulate PD-L1 [115]. Taken together, these data support the evaluation of PD-1 checkpoint inhibitors in the clinical setting. Kwong et al. described a case series of seven patients with relapsed ENKTL, all of whom responded to treatment with pembrolizumab, an antibody against PD1 [116]. Of note, two patients achieved a complete response in all parameters (clinical, radiologic, morphologic and molecular) assessed. PD-L1 expression data were available in five cases, four of which showed uniform strong expression and one showed weaker expression in $\sim 20 \%$ of the cells. The response to pembrolizumab, however, did not show a clear correlation with PD-L1 expression in tumor cells. Therefore, new biomarkers that can predict clinical response to checkpoint inhibition are needed [117].

A better understanding of the differential expression of PD-L1 and PD-1 on malignant versus immune cells in the microenvironment maybe a crucial step in the process of understanding responses to check point inhibitors. Most studies reporting upregulation of PD-L1 relied on single marker immunohistochemistry. Although visual scoring of staining intensity is of clinical value in the hands of an experienced hematopathologist, the data generated remain subjective with limited reproducibility [118]. Furthermore, there are several commercial clones of PD-L1 antibodies with different sensitivity and specificity. Currently, there remains a lack of standardization with regards to the staining protocol and quantification method with consequent variability in the data reported in the literature [119].

Adoptive immunotherapy using antigen-specific T cells targeting EBV-associated viral antigens has been employed in the treatment of ENKTL, with one study showing complete response in four out of six patients with active disease, and continued complete response in five of five patients in a first or later remission cohort [120]. In these patients, the therapy appeared to be well-tolerated, with 10 of 11 patients showing no toxicity attributed to the therapy, and one with a possible inflammatory response [120].

CD38 is a pleiotropic glycoprotein belonging to a complex family of enzymes of the cell surface and involved in the catabolism of extracellular nucleotides [121]. Our GEP data have demonstrated upregulation of CD38 gene in ENKTL tumor compared to control tissues (Table S3, GEO database GSE90597). CD38 protein is strongly expressed in 50\% of ENKTL and this is associated with significantly inferior outcomes compared to those with weak expression, indicating the potential role of CD38 as a therapy target [122]. The humanized monoclonal antibody, daratumumab, which targets CD38 has been approved for the treatment of relapsed multiple myeloma and is being explored in other lymphoproliferative disorders [123]. Recent in vitro studies revealed that daratumumab has good efficacy against ENKTL [124]. This was highlighted in the clinical setting by the dramatic response of a patient with relapsed refractory ENKTL to daratumumab monotherapy [125]. While these data suggest that CD38 is an attractive therapeutic target in ENKTL, most of the research on daratumumab has been in multiple myeloma and ENKTL-specific mechanisms of action and resistance will have to be investigated. 


\section{Opportunities for Translation}

\subsection{Refining Diagnosis}

The novel data gleaned from genome-wide high throughput techniques have greatly improved our understanding of the molecular biology of ENKTL and has significant impact on disease diagnosis and classification. These techniques have allowed the identification of the gene signature of ENKTL, the unique set of genes that defines the genomic characteristics of the tumor and distinguishes it from other PTCLs $[17,19,21]$. It has also shown that lymphomas originating from NK cells are molecularly related to those derived from a subset of $\gamma \delta$ T-cells that are characterized by a non-hepatosplenic presentation. Recent studies have further demonstrated that ENKTL is distinct from other overlapping and closely related diseases, such as EBV-positive T/NK-cell lymphomas presenting with nodal disease as well as those presenting in children and young adults [22,26]. While the data have led to an increased understanding of the tumor biology, the translation of the genomic data into clinically applicable diagnostic biomarkers remains challenging and confounded by the rarity of the disease and limited tissue availability.

\subsection{Risk Stratification}

Current risk stratification models of ENKTL utilize exclusively clinical criteria [126]. Recent studies have identified several molecular markers of potential prognostic significance in ENKTL. These include cytogenetic data, such as loss of 8p11.23, which correlated with a significantly worse prognosis in patients with ENKTL [57], mutational status of genes such as DDX3X and TP53 [76], and promoter methylation status of genes such as PTPRK [66]. In addition, tissue-based expression markers of potential prognostic significance include BLIMP1 [61] and miR-146a [97]. A circulating marker, miR-221, was also associated with a less favorable long-term outcome in ENKTL patients [104]. Whilst there is an emerging body of evidence to support the utility each of these markers, a direct comparison of their effectiveness against currently used clinical indices remains to be investigated. The early identification of patients who will not respond to standard therapy is important for the selection of these individuals for clinical trials with novel agents.

\subsection{Conclusions, Promising Therapeutic Targets and Future Directions}

Integration of massive sequencing strategies and gene expression has characterized the driver genetic alterations in ENKTL, as in other PTCLs [16]. These studies have identified oncogenic pathways that can be potentially targeted by specific therapies (Figure 3). While major advances in our understanding of the biology of ENKTL have been made in the last decade, the diagnosis and classification of ENKTL is likely to be further refined by GEP and other genomic techniques in the near future. The identification of potential tumor suppressor genes, PRDM1 and PTPRK, and pro-survival signaling via MYC and NF-KB are of particular importance as key events in ENKTL pathogenesis (Figure 3 and Table 3). Similarly, the discovery of transcriptional dysregulation through RUNX3 and non-canonical functions of EZH2 in ENKTL have shed new light on the molecular biology of this disease. Despite the biological importance of these findings, their clinical relevance remains to be established. From a therapeutic translational standpoint, we propose that immune checkpoint inhibition is one of the most promising avenues for drug development in ENKTL (Figure 3 and Table 3) [127]. Further work is necessary to establish the cell surface expression patterns of PD-1 and PD-L1 and a better understanding of the intracellular regulation of PD-L1 expression in this disease. The discovery of CMTM6 as a novel regulator of PD-L1 through endosomal recycling would be an interesting area for further studies in ENTKL [128]. Importantly, clinical trials evaluating check point inhibition for ENKTL in both relapsed and up front settings are required. Clinical trials evaluating JAK inhibition as a therapeutic strategy in ENKTL are ongoing, supported by the strong preclinical evidence of the dysregulation of this pathway. Finally, we propose that CD38 may be an attractive target for future clinical trials based on its strong and uniform expression in ENKTL along 
with promising early clinical data. It would be of great interest to assess the combination of anti-CD38 antibodies or JAK inhibitors in combination with L-asparaginase based chemotherapy in the up front or relapsed setting.

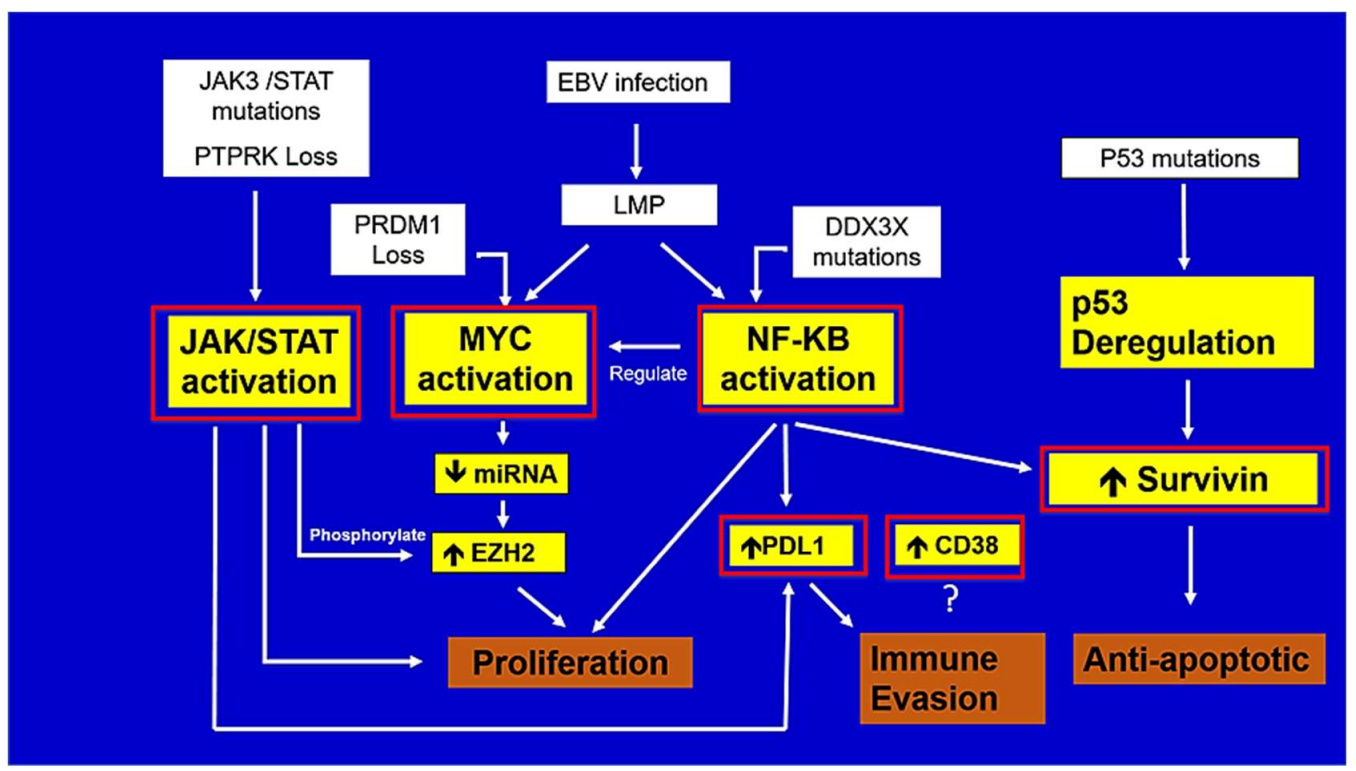

Figure 3. Proposed model of pathogenesis of ENKTL and potential therapeutic targets highlighted in red. EBV infection may provide a proliferative signal via MYC and NF-kB activation. JAK/STAT activation contributes through its known pro-proliferative functions and also via phosphorylation of EZH2 resulting in non-canonical activation of proliferative pathways. Anti-apoptotic effects may be driven by survivin as a result of p53 deregulation and NF-kB activation. Finally, PD-L1 plays a crucial role in immune evasion. The role of CD38 in the molecular biology of ENKTL is still under investigation.

Table 3. Therapeutic targets with the greatest translational potential in ENKTL.

\begin{tabular}{|c|c|c|}
\hline $\begin{array}{l}\text { Therapeutic Targets or } \\
\text { Signaling Pathway }\end{array}$ & Clinical Significance for Therapeutics & Reference \\
\hline JAK-3 & $\begin{array}{l}\text { JAK-3 inhibition is shown to have potent anti-tumor activity } \\
\text { in pre-clinical models. Clinical trials evaluating JAK } \\
\text { inhibitors in ENKTL are in progress. }\end{array}$ & $\begin{array}{l}\text { Sim et al. } 2017 \text { [77] } \\
\text { Narisimagi et al. } 2017 \text { [79] }\end{array}$ \\
\hline STAT-3 & $\begin{array}{l}\text { STAT-3 mutant ENKTL are sensitive to STAT-3 inhibition } \\
\text { in vitro. }\end{array}$ & Sim et al. 2017 [77] \\
\hline NF-kB & $\begin{array}{c}\text { NF-kB upregulation is an important event in ENKTL } \\
\text { pathogenesis. Bortezomib is being evaluated in early phase } \\
\text { clinical trials. }\end{array}$ & Tang et al. 2016 [49] \\
\hline CD38 & $\begin{array}{l}\text { CD38 is upregulated in ENKTL. Daratumumab has good } \\
\text { in vitro efficacy and one case report documenting } \\
\text { complete response. }\end{array}$ & $\begin{array}{l}\text { Mustafa et al. } 2017 \text { [124] } \\
\text { Hari et al. } 2016 \text { [125] }\end{array}$ \\
\hline PD-1 & $\begin{array}{l}\text { PD-L1 is upregulated in ENKTL. Early clinical trials show } \\
\text { potent single agent activity of anti PD- } 1 \text { therapy in relapsed, } \\
\text { refractory ENKTL. }\end{array}$ & Kwong et al. 2017 [116] \\
\hline
\end{tabular}

Supplementary Materials: Supplementary materials can be found at http:/ / www.mdpi.com/1422-0067/19/7/ $1931 /$ s1.

Author Contributions: Conceptualization, W.-J.C. and S.-B.N.; Data analysis, T.-H.C.; Writing-Original draft preparation, G.S.-T.S., Y.M., S.d.M. and S.-B.N.; and Writing-Review and editing, A.D.J. and W.-J.C.

Funding: S.-B.N. was supported by the Singapore Ministry of Health's National Medical Research Council Transition Award (NMRC/TA/0020/2013) and Translational \& Clinical Research (TCR) Flagship Programme (TCR12dec005).

Conflicts of Interest: The authors have no conflicts of interest to declare. 


\section{References}

1. Chan, J.K.C.; Quintanilla-Martinez, L.; Ferry, J.A. Extranodal nk/T-cell lymphoma, nasal type. In Who classification of tumours of haematopoietic and lymphoid tissues; Swerdlow, S.H., Campo, E., Harris, N.L., Jaffe, E.S., Pileri, S.A., Stein, H., Thiele, J., Arber, D.A., Hasserjian, R.P., Le Beau, M.M., et al., Eds.; International Agency for Research on Cancer: Lyon, France, 2017; pp. 368-371.

2. Ko, Y.H.; Chan, J.K.C.; Quintanilla-Martinez, L. Virally associated T-cell and NK-cell neoplasms. In Hematopathology, 2nd ed.; Jaffe, E.S., Arber, D.A., Campo, E., Harris, N.L., Quintanilla-Martinez, L., Eds.; Elsevier: Philadelphia, PA, USA, 2017; pp. 565-598.

3. $\mathrm{Ng}$, S.B.; Khoury, J.D. Epstein-barr virus in lymphoproliferative processes: An update for the diagnostic pathologist. Adv. Anat. Pathol. 2009, 16, 40-55. [CrossRef] [PubMed]

4. Suzumiya, J.; Ohshima, K.; Takeshita, M.; Kanda, M.; Kawasaki, C.; Kimura, N.; Tamura, K.; Kikuchi, M. Nasal lymphomas in japan: A high prevalence of epstein-barr virus type a and deletion within the latent membrane protein gene. Leuk. Lymphoma. 1999, 35, 567-578. [CrossRef] [PubMed]

5. Elenitoba-Johnson, K.S.; Zarate-Osorno, A.; Meneses, A.; Krenacs, L.; Kingma, D.W.; Raffeld, M.; Jaffe, E.S. Cytotoxic granular protein expression, epstein-barr virus strain type, and latent membrane protein-1 oncogene deletions in nasal T-lymphocyte/natural killer cell lymphomas from Mexico. Mod. Pathol 1998, 11, 754-761. [PubMed]

6. Huang, Y.; de Leval, L.; Gaulard, P. Molecular underpinning of extranodal NK/T-cell lymphoma. Best Pract. Res. Clin. Haematol. 2013, 26, 57-74. [CrossRef] [PubMed]

7. Attygalle, A.D.; Cabecadas, J.; Gaulard, P.; Jaffe, E.S.; de Jong, D.; Ko, Y.H.; Said, J.; Klapper, W. Peripheral T-cell and NK-cell lymphomas and their mimics; taking a step forward-Report on the lymphoma workshop of the XVIth meeting of the european association for haematopathology and the society for hematopathology. Histopathology 2014, 64, 171-199. [CrossRef] [PubMed]

8. Swerdlow, S.H.; Campo, E.; Pileri, S.A.; Harris, N.L.; Stein, H.; Siebert, R.; Advani, R.; Ghielmini, M.; Salles, G.A.; Zelenetz, A.D.; et al. The 2016 revision of the world health organization classification of lymphoid neoplasms. Blood 2016, 127, 2375-2390. [CrossRef] [PubMed]

9. Yamaguchi, M.; Kwong, Y.L.; Kim, W.S.; Maeda, Y.; Hashimoto, C.; Suh, C.; Izutsu, K.; Ishida, F.; Isobe, Y.; Sueoka, E.; et al. Phase ii study of smile chemotherapy for newly diagnosed stage iv, relapsed, or refractory extranodal natural killer (NK)/T-cell lymphoma, nasal type: The NK-cell tumor study group study. J. Clin. Oncol. 2011, 29, 4410-4416. [CrossRef] [PubMed]

10. Tse, E.; Kwong, Y.L. The diagnosis and management of NK/T -cell lymphomas. J. hematol. Oncol. 2017, 10, 85. [CrossRef] [PubMed]

11. Alizadeh, A.A.; Eisen, M.B.; Davis, R.E.; Ma, C.; Lossos, I.S.; Rosenwald, A.; Boldrick, J.C.; Sabet, H.; Tran, T.; $\mathrm{Yu}, \mathrm{X}$; ; et al. Distinct types of diffuse large B-cell lymphoma identified by gene expression profiling. Nature 2000, 403, 503-511. [CrossRef] [PubMed]

12. Strati, P.; Keating, M.J.; O’Brien, S.M.; Ferrajoli, A.; Burger, J.; Faderl, S.; Tambaro, F.P.; Jain, N.; Wierda, W.G. Outcomes of first-line treatment for chronic lymphocytic leukemia with 17p deletion. Haematologica 2014, 99, 1350-1355. [CrossRef] [PubMed]

13. Lemonnier, F.; Couronne, L.; Parrens, M.; Jais, J.P.; Travert, M.; Lamant, L.; Tournillac, O.; Rousset, T.; Fabiani, B.; Cairns, R.A.; et al. Recurrent TET2 mutations in peripheral T-cell lymphomas correlate with TFH-like features and adverse clinical parameters. Blood 2012, 120, 1466-1469. [CrossRef] [PubMed]

14. Wang, M.; Zhang, S.; Chuang, S.S.; Ashton-Key, M.; Ochoa, E.; Bolli, N.; Vassiliou, G.; Gao, Z.; Du, M.Q. Angioimmunoblastic T cell lymphoma: Novel molecular insights by mutation profiling. Oncotarget 2017, 8, 17763-17770. [CrossRef] [PubMed]

15. Couronne, L.; Bastard, C.; Bernard, O.A. Tet2 and dnmt3a mutations in human T-cell lymphoma. New Eng. J. Med. 2012, 366, 95-96. [CrossRef] [PubMed]

16. Iqbal, J.; Wilcox, R.; Naushad, H.; Rohr, J.; Heavican, T.B.; Wang, C.; Bouska, A.; Fu, K.; Chan, W.C.; Vose, J.M. Genomic signatures in T-cell lymphoma: How can these improve precision in diagnosis and inform prognosis? Blood Rev. 2016, 30, 89-100. [CrossRef] [PubMed]

17. Huang, Y.; de Reynies, A.; de Leval, L.; Ghazi, B.; Martin-Garcia, N.; Travert, M.; Bosq, J.; Briere, J.; Petit, B.; Thomas, E.; et al. Gene expression profiling identifies emerging oncogenic pathways operating in extranodal NK/T-cell lymphoma, nasal type. Blood 2010, 115, 1226-1237. [CrossRef] [PubMed] 
18. Iqbal, J.; Kucuk, C.; Deleeuw, R.J.; Srivastava, G.; Tam, W.; Geng, H.; Klinkebiel, D.; Christman, J.K.; Patel, K.; Cao, K.; et al. Genomic analyses reveal global functional alterations that promote tumor growth and novel tumor suppressor genes in natural killer-cell malignancies. Leukemia 2009, 23, 1139-1151. [CrossRef] [PubMed]

19. Iqbal, J.; Weisenburger, D.D.; Chowdhury, A.; Tsai, M.Y.; Srivastava, G.; Greiner, T.C.; Kucuk, C.; Deffenbacher, K.; Vose, J.; Smith, L.; et al. Natural killer cell lymphoma shares strikingly similar molecular features with a group of non-hepatosplenic gammadelta T-cell lymphoma and is highly sensitive to a novel aurora kinase a inhibitor in vitro. Leukemia 2011, 25, 348-358. [CrossRef] [PubMed]

20. Ng, S.B.; Selvarajan, V.; Huang, G.; Zhou, J.; Feldman, A.L.; Law, M.; Kwong, Y.L.; Shimizu, N.; Kagami, Y.; Aozasa, K.; et al. Activated oncogenic pathways and therapeutic targets in extranodal nasal-type NK/T cell lymphoma revealed by gene expression profiling. J. Pathol. 2011, 223, 496-510. [CrossRef] [PubMed]

21. Iqbal, J.; Wright, G.; Wang, C.; Rosenwald, A.; Gascoyne, R.D.; Weisenburger, D.D.; Greiner, T.C.; Smith, L.; Guo, S.; Wilcox, R.A.; et al. Gene expression signatures delineate biological and prognostic subgroups in peripheral T-cell lymphoma. Blood 2014, 123, 2915-2923. [CrossRef] [PubMed]

22. Ng, S.B.; Chung, T.H.; Kato, S.; Nakamura, S.; Takahashi, E.; Ko, Y.H.; Khoury, J.D.; Yin, C.C.; Soong, R.; Jeyasekharan, A.D.; et al. Epstein-barr virus-associated primary nodal $t / N K$-cell lymphoma shows a distinct molecular signature and copy number changes. Haematologica 2018, 103, 278-287. [CrossRef] [PubMed]

23. d'Amore, F.; Gaulard, P.; Trumper, L.; Corradini, P.; Kim, W.S.; Specht, L.; Bjerregaard Pedersen, M.; Ladetto, M.; Committee, E.G. Peripheral T-cell lymphomas: Esmo clinical practice guidelines for diagnosis, treatment and follow-up. Ann. Oncol. 2015, 26 Suppl. 5, v108-v115. [CrossRef] [PubMed]

24. Swerdlow, S.H.; Campo, E.; Harris, N.L.; Jaffe, E.S.; Pileri, S.A.; Stein, H.; Thiele, J.; Vardiman, J.W. Who Classification of Tumours of Haematopoietic and Lymphoid Tissues, 4th ed.; IARC: Lyon, France, 2017.

25. Ng, S.B.; Ohshima, K.; Selvarajan, V.; Huang, G.; Choo, S.N.; Miyoshi, H.; Wang, S.; Chua, H.C.; Yeoh, A.E.; Quah, T.C.; et al. Prognostic implication of morphology, cycline2 and proliferation in EBV-associated t/nk lymphoproliferative disease in non-immunocompromised hosts. Orphanet. J. Rare Dis. 2014, 9, 165. [CrossRef] [PubMed]

26. Ng, S.B.; Ohshima, K.; Selvarajan, V.; Huang, G.; Choo, S.N.; Miyoshi, H.; Shimizu, N.; Reghunathan, R.; Chua, H.C.; Yeoh, A.E.; et al. Epstein-barr virus-associated T/natural killer-cell lymphoproliferative disorder in children and young adults has similar molecular signature to extranodal nasal natural killer/T-cell lymphoma but shows distinctive stem cell-like phenotype. Leuk. Lymphoma. 2015, 56, 2408-2415. [CrossRef] [PubMed]

27. Andersen, M.H.; Svane, I.M.; Becker, J.C.; Straten, P.T. The universal character of the tumor-associated antigen survivin. Clin. Cancer Res. 2007, 13, 5991-5994. [CrossRef] [PubMed]

28. Anand, S.; Penrhyn-Lowe, S.; Venkitaraman, A.R. Aurora-a amplification overrides the mitotic spindle assembly checkpoint, inducing resistance to taxol. Cancer Cell 2003, 3, 51-62. [CrossRef]

29. Dutta-Simmons, J.; Zhang, Y.; Gorgun, G.; Gatt, M.; Mani, M.; Hideshima, T.; Takada, K.; Carlson, N.E.; Carrasco, D.E.; Tai, Y.T.; et al. Aurora kinase a is a target of wnt/beta-catenin involved in multiple myeloma disease progression. Blood 2009, 114, 2699-2708. [CrossRef] [PubMed]

30. Liu, Q.; Kaneko, S.; Yang, L.; Feldman, R.I.; Nicosia, S.V.; Chen, J.; Cheng, J.Q. Aurora-a abrogation of p53 DNA binding and transactivation activity by phosphorylation of serine 215. J. Biol. Chem. 2004, 279, 52175-52182. [CrossRef] [PubMed]

31. Yang, H.; Ou, C.C.; Feldman, R.I.; Nicosia, S.V.; Kruk, P.A.; Cheng, J.Q. Aurora-a kinase regulates telomerase activity through c-MYC in human ovarian and breast epithelial cells. Cancer Res. 2004, 64, 463-467. [CrossRef] [PubMed]

32. Ng, S.B.; Yan, J.; Huang, G.; Selvarajan, V.; Tay, J.L.; Lin, B.; Bi, C.; Tan, J.; Kwong, Y.L.; Shimizu, N.; et al. Dysregulated microRNAs affect pathways and targets of biologic relevance in nasal-type natural killer/T-cell lymphoma. Blood 2011, 118, 4919-4929. [CrossRef] [PubMed]

33. Jung, L.A.; Gebhardt, A.; Koelmel, W.; Ade, C.P.; Walz, S.; Kuper, J.; von Eyss, B.; Letschert, S.; Redel, C.; d'Artista, L.; et al. Omomyc blunts promoter invasion by oncogenic MYC to inhibit gene expression characteristic of MYC-dependent tumors. Oncogene 2017, 36, 1911-1924. [CrossRef] [PubMed]

34. Yan, J.; Ng, S.B.; Tay, J.L.; Lin, B.; Koh, T.L.; Tan, J.; Selvarajan, V.; Liu, S.C.; Bi, C.; Wang, S.; et al. Ezh2 overexpression in natural killer/T-cell lymphoma confers growth advantage independently of histone methyltransferase activity. Blood 2013, 121, 4512-4520. [CrossRef] [PubMed] 
35. Bracken, A.P.; Dietrich, N.; Pasini, D.; Hansen, K.H.; Helin, K. Genome-wide mapping of polycomb target genes unravels their roles in cell fate transitions. Genes Dev. 2006, 20, 1123-1136. [CrossRef] [PubMed]

36. Yan, J.; Li, B.; Lin, B.; Lee, P.T.; Chung, T.H.; Tan, J.; Bi, C.; Lee, X.T.; Selvarajan, V.; Ng, S.B.; et al. Ezh2 phosphorylation by JAK3 mediates a switch to noncanonical function in natural killer/T-cell lymphoma. Blood 2016, 128, 948-958. [CrossRef] [PubMed]

37. McCabe, M.T.; Ott, H.M.; Ganji, G.; Korenchuk, S.; Thompson, C.; Van Aller, G.S.; Liu, Y.; Graves, A.P.; Della Pietra, A., 3rd; Diaz, E.; et al. Ezh2 inhibition as a therapeutic strategy for lymphoma with EZH2-activating mutations. Nature 2012, 492, 108-112. [CrossRef] [PubMed]

38. Selvarajan, V.; Osato, M.; Nah, G.S.S.; Yan, J.; Chung, T.H.; Voon, D.C.; Ito, Y.; Ham, M.F.; Salto-Tellez, M.; Shimizu, N.; et al. RUNX3 is oncogenic in natural killer/T-cell lymphoma and is transcriptionally regulated by MYC. Leukemia 2017, 31, 2219-2227. [CrossRef] [PubMed]

39. Ito, Y.; Bae, S.C.; Chuang, L.S. The RUNX family: Developmental regulators in cancer. Nat. Rev. Cancer 2015, 15, 81-95. [CrossRef] [PubMed]

40. Cruz-Guilloty, F.; Pipkin, M.E.; Djuretic, I.M.; Levanon, D.; Lotem, J.; Lichtenheld, M.G.; Groner, Y.; Rao, A. RUNX3 and T-box proteins cooperate to establish the transcriptional program of effector CTLs. J. Exp. Med. 2009, 206, 51-59. [CrossRef] [PubMed]

41. Coppo, P.; Gouilleux-Gruart, V.; Huang, Y.; Bouhlal, H.; Bouamar, H.; Bouchet, S.; Perrot, C.; Vieillard, V.; Dartigues, P.; Gaulard, P.; et al. STAT3 transcription factor is constitutively activated and is oncogenic in nasal-type NK/T-cell lymphoma. Leukemia 2009, 23, 1667-1678. [CrossRef] [PubMed]

42. Lee, S.; Park, H.Y.; Kang, S.Y.; Kim, S.J.; Hwang, J.; Lee, S.; Kwak, S.H.; Park, K.S.; Yoo, H.Y.; Kim, W.S.; et al. Genetic alterations of JAK/STAT cascade and histone modification in extranodal NK/T-cell lymphoma nasal type. Oncotarget 2015, 6, 17764-17776. [CrossRef] [PubMed]

43. Kimura, H.; Karube, K.; Ito, Y.; Hirano, K.; Suzuki, M.; Iwata, S.; Seto, M. Rare occurrence of jak3 mutations in natural killer cell neoplasms in japan. Leuk. Lymphoma. 2014, 55, 962-963. [CrossRef] [PubMed]

44. Koo, G.C.; Tan, S.Y.; Tang, T.; Poon, S.L.; Allen, G.E.; Tan, L.; Chong, S.C.; Ong, W.S.; Tay, K.; Tao, M.; et al. Janus kinase 3-activating mutations identified in natural killer/T-cell lymphoma. Cancer Discov. 2012, 2, 591-597. [CrossRef] [PubMed]

45. Guo, Y.; Arakawa, F.; Miyoshi, H.; Niino, D.; Kawano, R.; Ohshima, K. Activated janus kinase 3 expression not by activating mutations identified in natural killer/T-cell lymphoma. Pathol. Int. 2014, 64, 263-266. [CrossRef] [PubMed]

46. Bouchekioua, A.; Scourzic, L.; de Wever, O.; Zhang, Y.; Cervera, P.; Aline-Fardin, A.; Mercher, T.; Gaulard, P.; Nyga, R.; Jeziorowska, D.; et al. JAK3 deregulation by activating mutations confers invasive growth advantage in extranodal nasal-type natural killer cell lymphoma. Leukemia 2014, 28, 338-348. [CrossRef] [PubMed]

47. Andrae, J.; Gallini, R.; Betsholtz, C. Role of platelet-derived growth factors in physiology and medicine. Genes Dev. 2008, 22, 1276-1312. [CrossRef] [PubMed]

48. Chen, C.; He, H. Treatment of relapsed extranodal natural killer/T-cell lymphoma with bortezomib plus fludarabine. Mol. Clin. Oncol. 2017, 7, 525-528. [CrossRef] [PubMed]

49. Tang, T.; Tay, K.; Tao, M.; Quek, R.H.H.; Farid, M.; Lim, S.T. A phase ii study of bortezomib-gifox (gemcitabine, ifosfamide, oxaliplatin) in patients with newly diagnosed natural-killer/T-cell lymphoma. Blood 2016, 128, 5353.

50. Schmitt, C.; Sako, N.; Bagot, M.; Huang, Y.; Gaulard, P.; Bensussan, A. Extranodal NK/T-cell lymphoma: Toward the identification of clinical molecular targets. J. Biomed. Biotechnol. 2011, 2011, 790871. [CrossRef] [PubMed]

51. Ganjoo, K.; Hong, F.; Horning, S.J.; Gascoyne, R.D.; Natkunam, Y.; Swinnen, L.J.; Habermann, T.M.; Kahl, B.S.; Advani, R.H. Bevacizumab and cyclosphosphamide, doxorubicin, vincristine and prednisone in combination for patients with peripheral T-cell or natural killer cell neoplasms: An eastern cooperative oncology group study (e2404). Leuk. Lymphoma. 2014, 55, 768-772. [CrossRef] [PubMed]

52. Westin, J.R. Status of PI3K/Akt/mTOR pathway inhibitors in lymphoma. Clin Lymph. Myeloma Leuk. 2014, 14, 335-342. [CrossRef] [PubMed] 
53. Ko, Y.H.; Choi, K.E.; Han, J.H.; Kim, J.M.; Ree, H.J. Comparative genomic hybridization study of nasal-type NK/T-cell lymphoma. Cytometry 2001, 46, 85-91. [CrossRef] [PubMed]

54. Nakashima, Y.; Tagawa, H.; Suzuki, R.; Karnan, S.; Karube, K.; Ohshima, K.; Muta, K.; Nawata, H.; Morishima, Y.; Nakamura, S.; et al. Genome-wide array-based comparative genomic hybridization of natural killer cell lymphoma/leukemia: Different genomic alteration patterns of aggressive NK-cell leukemia and extranodal NK/T-cell lymphoma, nasal type. Genes Chromosomes Cancer 2005, 44, 247-255. [CrossRef] [PubMed]

55. Siu, L.L.; Chan, V.; Chan, J.K.; Wong, K.F.; Liang, R.; Kwong, Y.L. Consistent patterns of allelic loss in natural killer cell lymphoma. Am. J. Pathol. 2000, 157, 1803-1809. [CrossRef]

56. Siu, L.L.; Wong, K.F.; Chan, J.K.; Kwong, Y.L. Comparative genomic hybridization analysis of natural killer cell lymphoma/leukemia. Recognition of consistent patterns of genetic alterations. Am. J. Pathol. 1999, 155, 1419-1425. [CrossRef]

57. Sun, L.; Li, M.; Huang, X.; Xu, J.; Gao, Z.; Liu, C. High-resolution genome-wide analysis identified recurrent genetic alterations in NK/T-cell lymphoma, nasal type, which are associated with disease progression. Med. Oncol. 2014, 31, 71. [CrossRef] [PubMed]

58. Sun, H.S.; Su, I.J.; Lin, Y.C.; Chen, J.S.; Fang, S.Y. A $2.6 \mathrm{mb}$ interval on chromosome 6q25.2-q25.3 is commonly deleted in human nasal natural killer/T-cell lymphoma. Br. J. Haematol. 2003, 122, 590-599. [CrossRef] [PubMed]

59. Minnich, M.; Tagoh, H.; Bonelt, P.; Axelsson, E.; Fischer, M.; Cebolla, B.; Tarakhovsky, A.; Nutt, S.L.; Jaritz, M.; Busslinger, M. Multifunctional role of the transcription factor Blimp-1 in coordinating plasma cell differentiation. Nat. Immunol. 2016, 17, 331-343. [CrossRef] [PubMed]

60. Zhang, Z.; Liang, L.; Li, D.; Nong, L.; Liu, J.; Qu, L.; Zheng, Y.; Zhang, B.; Li, T. Hypermethylation of PRDM1/Blimp-1 promoter in extranodal NK/T-cell lymphoma, nasal type: An evidence of predominant role in its downregulation. Hematol. Oncol. 2017, 35, 645-654. [CrossRef] [PubMed]

61. Liang, L.; Nong, L.; Zhang, S.; Zhao, J.; Ti, H.; Dong, Y.; Zhang, B.; Li, T. The downregulation of PRDM1/Blimp-1 is associated with aberrant expression of mir-223 in extranodal NK/T-cell lymphoma, nasal type. J. Exp. Clin. Cancer Res. 2014, 33, 7. [CrossRef] [PubMed]

62. Zhang, L.; Anglesio, M.S.; O'Sullivan, M.; Zhang, F.; Yang, G.; Sarao, R.; Mai, P.N.; Cronin, S.; Hara, H.; Melnyk, N.; et al. The e3 ligase hace1 is a critical chromosome 6q21 tumor suppressor involved in multiple cancers. Nat. Med. 2007, 13, 1060-1069. [CrossRef] [PubMed]

63. Kucuk, C.; Hu, X.; Iqbal, J.; Gaulard, P.; Klinkebiel, D.; Cornish, A.; Dave, B.J.; Chan, W.C. Hace1 is a tumor suppressor gene candidate in natural killer cell neoplasms. Am. J. Pathol. 2013, 182, 49-55. [CrossRef] [PubMed]

64. Sako, N.; Dessirier, V.; Bagot, M.; Bensussan, A.; Schmitt, C. Hace1, a potential tumor suppressor gene on 6q21, is not involved in extranodal natural killer/T-cell lymphoma pathophysiology. Am. J. Pathol. 2014, 184, 2899-2907. [CrossRef] [PubMed]

65. Schmitt, C.; Sako, N.; Bagot, M.; Bensussan, A. Lack of evidence that hace1 is not a tumor suppressor gene in NKTCL: To the editor-in-chief. Authors' reply. Am. J. Pathol. 2015, 185, 1168. [CrossRef] [PubMed]

66. Chen, Y.W.; Guo, T.; Shen, L.; Wong, K.Y.; Tao, Q.; Choi, W.W.; Au-Yeung, R.K.; Chan, Y.P.; Wong, M.L.; Tang, J.C.; et al. Receptor-type tyrosine-protein phosphatase kappa directly targets stat3 activation for tumor suppression in nasal NK/T-cell lymphoma. Blood 2015, 125, 1589-1600. [CrossRef] [PubMed]

67. Yousefi, S.; Perozzo, R.; Schmid, I.; Ziemiecki, A.; Schaffner, T.; Scapozza, L.; Brunner, T.; Simon, H.U. Calpain-mediated cleavage of ATG5 switches autophagy to apoptosis. Nat. Cell Biol. 2006, 8, 1124-1132. [CrossRef] [PubMed]

68. Haffner, M.C.; Esopi, D.M.; Chaux, A.; Gurel, M.; Ghosh, S.; Vaghasia, A.M.; Tsai, H.; Kim, K.; Castagna, N.; Lam, H.; et al. Aim1 is an actin-binding protein that suppresses cell migration and micrometastatic dissemination. Nat. Commun. 2017, 8, 142. [CrossRef] [PubMed]

69. Karube, K.; Nakagawa, M.; Tsuzuki, S.; Takeuchi, I.; Honma, K.; Nakashima, Y.; Shimizu, N.; Ko, Y.H.; Morishima, Y.; Ohshima, K.; et al. Identification of FOXO3 and PRDM1 as tumor-suppressor gene candidates in NK-cell neoplasms by genomic and functional analyses. Blood 2011, 118, 3195-3204. [CrossRef] [PubMed]

70. Adams, S.V.; Newcomb, P.A.; Shustov, A.R. Racial patterns of peripheral T-cell lymphoma incidence and survival in the united states. J. Clin. Oncol. 2016, 34, 963-971. [CrossRef] [PubMed] 
71. Kanno, H.; Kojya, S.; Li, T.; Ohsawa, M.; Nakatsuka, S.; Miyaguchi, M.; Harabuchi, Y.; Aozasa, K. Low frequency of HLA-A*0201 allele in patients with Epstein-Barr virus-positive nasal lymphomas with polymorphic reticulosis morphology. Int. J Cancer 2000, 87, 195-199. [CrossRef]

72. Li, Z.; Xia, Y.; Feng, L.N.; Chen, J.R.; Li, H.M.; Cui, J.; Cai, Q.Q.; Sim, K.S.; Nairismagi, M.L.; Laurensia, Y.; et al. Genetic risk of extranodal natural killer T-cell lymphoma: A genome-wide association study. Lancet. Oncol. 2016, 17, 1240-1247. [CrossRef]

73. Klein, J.; Sato, A. The hla system. First of two parts. New Eng. J. Med. 2000, 343, 702-709. [CrossRef] [PubMed]

74. Kamatani, Y.; Wattanapokayakit, S.; Ochi, H.; Kawaguchi, T.; Takahashi, A.; Hosono, N.; Kubo, M.; Tsunoda, T.; Kamatani, N.; Kumada, H.; et al. A genome-wide association study identifies variants in the hla-dp locus associated with chronic hepatitis b in Asians. Nat. Genet. 2009, 41, 591-595. [CrossRef] [PubMed]

75. Wang, K.; Yang, H.; He, W.; Xia, Y.; Xia, Z.; Li, S.; Huang, H.; Li, Z.; Liu, P.; Jiang, W. Association between extranodal natural killer/T-cell lymphoma and hepatitis b viral infection: A case-control study. J. Cancer 2017, 8, 2676-2683. [CrossRef] [PubMed]

76. Jiang, L.; Gu, Z.H.; Yan, Z.X.; Zhao, X.; Xie, Y.Y.; Zhang, Z.G.; Pan, C.M.; Hu, Y.; Cai, C.P.; Dong, Y.; et al. Exome sequencing identifies somatic mutations of DDX3X in natural killer/T-cell lymphoma. Nat. Genet. 2015, 47, 1061-1066. [CrossRef] [PubMed]

77. Sim, S.H.; Kim, S.; Kim, T.M.; Jeon, Y.K.; Nam, S.J.; Ahn, Y.O.; Keam, B.; Park, H.H.; Kim, D.W.; Kim, C.W.; et al. Novel JAK3-activating mutations in extranodal NK/T-cell lymphoma, nasal type. Am. J. Pathol. 2017, 187, 980-986. [CrossRef] [PubMed]

78. Kucuk, C.; Jiang, B.; Hu, X.; Zhang, W.; Chan, J.K.; Xiao, W.; Lack, N.; Alkan, C.; Williams, J.C.; Avery, K.N.; et al. Activating mutations of STAT5B and STAT3 in lymphomas derived from gammadelta-T or NK cells. Nat. Commun. 2015, 6, 6025. [CrossRef] [PubMed]

79. Nairismagi, M.; Gerritsen, M.E.; Li, Z.M.; Wijaya, G.C.; Chia, B.K.H.; Laurensia, Y.; Lim, J.Q.; Yeoh, K.W.; Yao, X.S.; Pang, W.L.; et al. Oncogenic activation of JAK3-STAT signaling confers clinical sensitivity to PRN371, a novel selective and potent JAK3 inhibitor, in natural killer/T-cell lymphoma. Leukemia 2018, 32, 1147-1156. [CrossRef] [PubMed]

80. Zhang, Y.; Xu, W.; Liu, H.; Li, J. Therapeutic options in peripheral T cell lymphoma. J. Hematol. Oncol. 2016, 9, 37. [CrossRef] [PubMed]

81. Huynh, K.D.; Fischle, W.; Verdin, E.; Bardwell, V.J. Bcor, a novel corepressor involved in BCL-6 repression. Genes Dev. 2000, 14, 1810-1823. [PubMed]

82. Milne, T.A.; Briggs, S.D.; Brock, H.W.; Martin, M.E.; Gibbs, D.; Allis, C.D.; Hess, J.L. Mll targets SET domain methyltransferase activity to Hox gene promoters. Mol. Cell 2002, 10, 1107-1117. [CrossRef]

83. Dobashi, A.; Tsuyama, N.; Asaka, R.; Togashi, Y.; Ueda, K.; Sakata, S.; Baba, S.; Sakamoto, K.; Hatake, K.; Takeuchi, K. Frequent bcor aberrations in extranodal NK/T-cell lymphoma, nasal type. Genes Chromosom. Cancer 2016, 55, 460-471. [CrossRef] [PubMed]

84. Vousden, K.H.; Lane, D.P. P53 in health and disease. Nature Reviews Molecular Cell. Biology 2007, 8, 275. [CrossRef] [PubMed]

85. Li, T.; Hongyo, T.; Syaifudin, M.; Nomura, T.; Dong, Z.; Shingu, N.; Kojya, S.; Nakatsuka, S.; Aozasa, K. Mutations of the $p 53$ gene in nasal NK/T-cell lymphoma. Lab. Invest. 2000, 80, 493-499. [CrossRef] [PubMed]

86. Takahara, M.; Kishibe, K.; Bandoh, N.; Nonaka, S.; Harabuchi, Y. P53, N- and K-Ras, and beta-catenin gene mutations and prognostic factors in nasal NK/T-cell lymphoma from Hokkaido, Japan. Hum. Pathol. 2004, 35, 86-95. [CrossRef] [PubMed]

87. Kurniawan, A.N.; Hongyo, T.; Hardjolukito, E.S.; Ham, M.F.; Takakuwa, T.; Kodariah, R.; Hoshida, Y.; Nomura, T.; Aozasa, K. Gene mutation analysis of sinonasal lymphomas in indonesia. Oncol. Rep. 2006, 15, 1257-1263. [CrossRef] [PubMed]

88. Hongyo, T.; Hoshida, Y.; Nakatsuka, S.; Syaifudin, M.; Kojya, S.; Yang, W.I.; Min, Y.H.; Chan, H.; Kim, C.H.; Harabuchi, Y.; et al. P53, K-ras, c-kit and beta-catenin gene mutations in sinonasal NK/T-cell lymphoma in korea and japan. Oncol. Rep. 2005, 13, 265-271. [PubMed]

89. Quintanilla-Martinez, L.; Kremer, M.; Keller, G.; Nathrath, M.; Gamboa-Dominguez, A.; Meneses, A.; Luna-Contreras, L.; Cabras, A.; Hoefler, H.; Mohar, A.; et al. P53 mutations in nasal natural killer/T-cell 
lymphoma from mexico: Association with large cell morphology and advanced disease. Am. J. Pathol. 2001, 159, 2095-2105. [CrossRef]

90. Takakuwa, T.; Dong, Z.; Nakatsuka, S.; Kojya, S.; Harabuchi, Y.; Yang, W.I.; Nagata, S.; Aozasa, K. Frequent mutations of fas gene in nasal NK/T cell lymphoma. Oncogene 2002, 21, 4702-4705. [CrossRef] [PubMed]

91. Wi, S.M.; Moon, G.; Kim, J.; Kim, S.T.; Shim, J.H.; Chun, E.; Lee, K.Y. TAK1-ECSIT-TRAF6 complex plays a key role in the TLR4 signal to activate NF-kappab. J. Biol. Chem. 2014, 289, 35205-35214. [CrossRef] [PubMed]

92. Wen, H.; Ma, H.; Cai, Q.; Lin, S.; Lei, X.; He, B.; Wu, S.; Wang, Z.; Gao, Y.; Liu, W.; et al. Recurrent ecsit mutation encoding v140a triggers hyperinflammation and promotes hemophagocytic syndrome in extranodal NK/T cell lymphoma. Nat. Med. 2018. [CrossRef] [PubMed]

93. Abbaspour Babaei, M.; Kamalidehghan, B.; Saleem, M.; Huri, H.Z.; Ahmadipour, F. Receptor tyrosine kinase (c-kit) inhibitors: A potential therapeutic target in cancer cells. Drug Des. Devel. Ther. 2016, 10, 2443-2459. [CrossRef] [PubMed]

94. Hongyo, T.; Li, T.; Syaifudin, M.; Baskar, R.; Ikeda, H.; Kanakura, Y.; Aozasa, K.; Nomura, T. Specific c-kit mutations in sinonasal natural killer/T-cell lymphoma in China and Japan. Cancer Res. 2000, 60, 2345-2347. [PubMed]

95. Hoshida, Y.; Hongyo, T.; Jia, X.; He, Y.; Hasui, K.; Dong, Z.; Luo, W.J.; Ham, M.F.; Nomura, T.; Aozasa, K. Analysis of p53, K-ras, c-kit, and beta-catenin gene mutations in sinonasal NK/T cell lymphoma in northeast district of China. Cancer Sci. 2003, 94, 297-301. [CrossRef] [PubMed]

96. Kucuk, C.; Hu, X.; Jiang, B.; Klinkebiel, D.; Geng, H.; Gong, Q.; Bouska, A.; Iqbal, J.; Gaulard, P.; McKeithan, T.W.; et al. Global promoter methylation analysis reveals novel candidate tumor suppressor genes in natural killer cell lymphoma. Clin. Cancer Res. 2015, 21, 1699-1711. [CrossRef] [PubMed]

97. Paik, J.H.; Jang, J.Y.; Jeon, Y.K.; Kim, W.Y.; Kim, T.M.; Heo, D.S.; Kim, C.W. MicroRNA-146a downregulates nfkappab activity via targeting TRAF6 and functions as a tumor suppressor having strong prognostic implications in NK/T cell lymphoma. Clin. Cancer Res. 2011, 17, 4761-4771. [CrossRef] [PubMed]

98. Bartel, D.P. MicroRNAs: Target recognition and regulatory functions. Cell 2009, 136, 215-233. [CrossRef] [PubMed]

99. Beaulieu, A.M.; Bezman, N.A.; Lee, J.E.; Matloubian, M.; Sun, J.C.; Lanier, L.L. MicroRNA function in NK-cell biology. Immunol. Rev. 2013, 253, 40-52. [CrossRef] [PubMed]

100. Sullivan, R.P.; Leong, J.W.; Fehniger, T.A. MicroRNA regulation of natural killer cells. Front. Immunol. 2013, 4, 44. [CrossRef] [PubMed]

101. Saki, N.; Abroun, S.; Soleimani, M.; Hajizamani, S.; Shahjahani, M.; Kast, R.E.; Mortazavi, Y. Involvement of microRNA in T-cell differentiation and malignancy. Int. J. Hematol. Stem Cell Res. 2015, 9, 33-49.

102. Motsch, N.; Alles, J.; Imig, J.; Zhu, J.; Barth, S.; Reineke, T.; Tinguely, M.; Cogliatti, S.; Dueck, A.; Meister, G.; et al. MicroRNA profiling of epstein-barr virus-associated NK/T-cell lymphomas by deep sequencing. PLoS ONE 2012, 7, e42193. [CrossRef] [PubMed]

103. Yamanaka, Y.; Tagawa, H.; Takahashi, N.; Watanabe, A.; Guo, Y.M.; Iwamoto, K.; Yamashita, J.; Saitoh, H.; Kameoka, Y.; Shimizu, N.; et al. Aberrant overexpression of microRNAs activate AKT signaling via down-regulation of tumor suppressors in natural killer-cell lymphoma/leukemia. Blood 2009, 114, 3265-3275. [CrossRef] [PubMed]

104. Guo, H.Q.; Huang, G.L.; Guo, C.C.; Pu, X.X.; Lin, T.Y. Diagnostic and prognostic value of circulating mir-221 for extranodal natural killer/T-cell lymphoma. Dis. Markers 2010, 29, 251-258. [CrossRef] [PubMed]

105. Watanabe, A.; Tagawa, H.; Yamashita, J.; Teshima, K.; Nara, M.; Iwamoto, K.; Kume, M.; Kameoka, Y.; Takahashi, N.; Nakagawa, T.; et al. The role of microRNA-150 as a tumor suppressor in malignant lymphoma. Leukemia 2011, 25, 1324-1334. [CrossRef] [PubMed]

106. Huang, H.; Fan, L.; Zhan, R.; Wu, S.; Niu, W. Expression of microRNA-10a, microRNA-342-3p and their predicted target gene tiam1 in extranodal NK/T-cell lymphoma, nasal type. Oncol. Lett. 2016, 11, 345-351. [CrossRef] [PubMed]

107. Ramakrishnan, R.; Donahue, H.; Garcia, D.; Tan, J.; Shimizu, N.; Rice, A.P.; Ling, P.D. Epstein-Barr virus BART9 mirna modulates LMP1 levels and affects growth rate of nasal NK T cell lymphomas. PLoS ONE 2011, 6, e27271. [CrossRef] [PubMed] 
108. Chang, T.C.; Yu, D.; Lee, Y.S.; Wentzel, E.A.; Arking, D.E.; West, K.M.; Dang, C.V.; Thomas-Tikhonenko, A.; Mendell, J.T. Widespread microRNA repression by MYC contributes to tumorigenesis. Nat. Genet. 2008, 40, 43-50. [CrossRef] [PubMed]

109. Godshalk, S.E.; Bhaduri-McIntosh, S.; Slack, F.J. Epstein-barr virus-mediated dysregulation of human microRNA expression. Cell Cycle 2008, 7, 3595-3600. [CrossRef] [PubMed]

110. Gatto, G.; Rossi, A.; Rossi, D.; Kroening, S.; Bonatti, S.; Mallardo, M. Epstein-Barr virus latent membrane protein 1 trans-activates miR-155 transcription through the NF-kappab pathway. Nucleic Acids Res. 2008, 36, 6608-6619. [CrossRef] [PubMed]

111. Wong, K.Y.; So, C.C.; Loong, F.; Chung, L.P.; Lam, W.W.; Liang, R.; Li, G.K.; Jin, D.Y.; Chim, C.S. Epigenetic inactivation of the miR-124-1 in haematological malignancies. PLoS ONE 2011, 6, e19027. [CrossRef] [PubMed]

112. Boussiotis, V.A. Molecular and biochemical aspects of the PD-1 checkpoint pathway. New Eng. J. Med. 2016, 375, 1767-1778. [CrossRef] [PubMed]

113. Chen, B.J.; Chapuy, B.; Ouyang, J.; Sun, H.H.; Roemer, M.G.; Xu, M.L.; Yu, H.; Fletcher, C.D.; Freeman, G.J.; Shipp, M.A.; et al. PD-L1 expression is characteristic of a subset of aggressive B-cell lymphomas and virus-associated malignancies. Clin. Cancer Res. 2013, 19, 3462-3473. [CrossRef] [PubMed]

114. Bi, X.W.; Wang, H.; Zhang, W.W.; Wang, J.H.; Liu, W.J.; Xia, Z.J.; Huang, H.Q.; Jiang, W.Q.; Zhang, Y.J.; Wang, L. Pd-11 is upregulated by EBV-driven LMP1 through NF-kappab pathway and correlates with poor prognosis in natural killer/T-cell lymphoma. J. Hematol. Oncol. 2016, 9, 109. [CrossRef] [PubMed]

115. Lim, S.T.; Song, T.; Lim, J.Q.; Laurensia, Y.; Pang, J.W.L.; Nagarajan, S.; Claresta, G.; Jing, T.; Tang, T.P.L.; Nairismagi, M.-L.; et al. Oncogenic activation of STAT3 pathway drives PD-L1 expression in natural killer/T cell lymphoma. J. Clin. Oncol. 2017, 35, 7549.

116. Kwong, Y.L.; Chan, T.S.Y.; Tan, D.; Kim, S.J.; Poon, L.M.; Mow, B.; Khong, P.L.; Loong, F.; Au-Yeung, R.; Iqbal, J.; et al. Pd1 blockade with pembrolizumab is highly effective in relapsed or refractory NK/T-cell lymphoma failing 1-asparaginase. Blood 2017, 129, 2437-2442. [CrossRef] [PubMed]

117. Ok, C.Y.; Young, K.H. Checkpoint inhibitors in hematological malignancies. J Hematol. Oncol. 2017, 10, 103. [CrossRef] [PubMed]

118. Rizzardi, A.E.; Johnson, A.T.; Vogel, R.I.; Pambuccian, S.E.; Henriksen, J.; Skubitz, A.P.; Metzger, G.J.; Schmechel, S.C. Quantitative comparison of immunohistochemical staining measured by digital image analysis versus pathologist visual scoring. Diagn. Pathol. 2012, 7, 42. [CrossRef] [PubMed]

119. Parra, E.R.; Villalobos, P.; Mino, B.; Rodriguez-Canales, J. Comparison of different antibody clones for immunohistochemistry detection of programmed cell death ligand 1 (pd-11) on non-small cell lung carcinoma. Appl. Immunohistochem. Mol. Morphol. 2018, 26, 83-93. [CrossRef] [PubMed]

120. Bollard, C.M.; Gottschalk, S.; Torrano, V.; Diouf, O.; Ku, S.; Hazrat, Y.; Carrum, G.; Ramos, C.; Fayad, L.; Shpall, E.J.; et al. Sustained complete responses in patients with lymphoma receiving autologous cytotoxic t lymphocytes targeting Epstein-Barr virus latent membrane proteins. J. Clin. Oncol. 2014, 32, 798-808. [CrossRef] [PubMed]

121. Malavasi, F.; Funaro, A.; Roggero, S.; Horenstein, A.; Calosso, L.; Mehta, K. Human CD38: A glycoprotein in search of a function. Immunol. Today 1994, 15, 95-97. [CrossRef]

122. Wang, L.; Wang, H.; Li, P.F.; Lu, Y.; Xia, Z.J.; Huang, H.Q.; Zhang, Y.J. CD38 expression predicts poor prognosis and might be a potential therapy target in extranodal NK/T cell lymphoma, nasal type. Ann. Hematol. 2015, 94, 1381-1388. [CrossRef] [PubMed]

123. Lokhorst, H.M.; Plesner, T.; Laubach, J.P.; Nahi, H.; Gimsing, P.; Hansson, M.; Minnema, M.C.; Lassen, U.; Krejcik, J.; Palumbo, A.; et al. Targeting CD38 with daratumumab monotherapy in multiple myeloma. New Eng. J. Med. 2015, 373, 1207-1219. [CrossRef] [PubMed]

124. Mustafa, N.; Nee, H.F.A.; Lee, X.T.J.; Jin, W.; Yu, Y.; Chen, Y.; Yang, J.; Chng, W.J. Daratumumab efficiently targets NK/T cell lymphoma with high CD38 expression. Blood 2017, 130, 2814.

125. Hari, P.; Raj, R.V.; Olteanu, H. Targeting CD38 in refractory extranodal natural killer cell-T-cell lymphoma. New Eng. J. Med. 2016, 375, 1501-1502. [CrossRef] [PubMed]

126. Kim, S.J.; Choi, J.Y.; Hyun, S.H.; Ki, C.S.; Oh, D.; Ahn, Y.C.; Ko, Y.H.; Choi, S.; Jung, S.H.; Khong, P.L.; et al. Risk stratification on the basis of deauville score on pet-ct and the presence of epstein-barr virus DNA after completion of primary treatment for extranodal natural killer/T-cell lymphoma, nasal type: A multicentre, retrospective analysis. Lancet. Haematol. 2015, 2, e66-e74. [CrossRef] 
127. Jaccard, A.; Hermine, O. A major turning point in NK/T-cell lymphoma? Blood 2017, 129, $2342-2343$. [CrossRef] [PubMed]

128. Burr, M.L.; Sparbier, C.E.; Chan, Y.C.; Williamson, J.C.; Woods, K.; Beavis, P.A.; Lam, E.Y.N.; Henderson, M.A.; Bell, C.C.; Stolzenburg, S.; et al. CMTM6 maintains the expression of pd-11 and regulates anti-tumour immunity. Nature 2017, 549, 101-105. [CrossRef] [PubMed] 